\title{
Adult body growth and reproductive investment vary markedly within and across Atlantic and Pacific herring: a meta-analysis and review of 26 stocks
}

\author{
Thassya C. dos Santos Schmidt $\mathbb{D} \cdot$ Doug E. Hay - Svein Sundby $\mathbb{D} \cdot$ \\ Jennifer A. Devine (D) G Guðmundur J. Óskarsson $(\mathbb{D} \cdot$ Aril Slotte • \\ Mark J. Wuenschel (1) - Dmitry Lajus $(\mathbb{D} \cdot$ Arne Johannessen • Cindy J. G. van Damme (i) \\ Rikke H. Bucholtz • Olav S. Kjesbu (D)
}

Received: 20 February 2020/ Accepted: 31 May 2021 / Published online: 7 June 2021

(C) The Author(s) 2021

\begin{abstract}
Life-history traits of Pacific (Clupea pallasii) and Atlantic (Clupea harengus) herring, comprising both local and oceanic stocks subdivided into summer-autumn and spring spawners, were extensively reviewed. The main parameters investigated were body growth, condition, and reproductive investment. Body size of Pacific herring increased with increasing latitude. This pattern was inconsistent for Atlantic herring. Pacific and local Norwegian herring showed comparable body conditions, whereas oceanic
\end{abstract}

Supplementary Information The online version contains supplementary material available at https://doi.org/10.1007/ s11160-021-09665-9.

T. C. dos Santos Schmidt $(\bowtie) \cdot$ S. Sundby •

A. Slotte - O. S. Kjesbu

Institute of Marine Research, Nordnes, PO Box 1870,

5817 Bergen, Norway

e-mail: thassya@hi.no

T. C. dos Santos Schmidt · A. Johannessen

Department of Biological Sciences, University of Bergen,

PO Box 7803, 5020 Bergen, Norway

D. E. Hay

Pacific Biological Station, Fisheries and Oceans Canada, Emeritus Scientist, PO Box 3190, Nanaimo,

BC V9T 6N7, Canada

J. A. Devine

National Institute of Water \& Atmospheric Research Ltd., 217 Akersten St, Port Nelson, Nelson 7010, New Zealand
Atlantic herring generally appeared stouter. Among Atlantic herring, summer and autumn spawners produced many small eggs compared to spring spawners, which had fewer but larger eggs-findings agreeing with statements given several decades ago. The 26 herring stocks we analysed, when combined across distant waters, showed clear evidence of a trade-off between fecundity and egg size. The size-specific individual variation, often ignored, was substantial. Additional information on biometrics clarified that oceanic stocks were generally larger and had longer life spans than local herring stocks, probably related to their longer feeding migrations. Body condition was

\section{G. J. Óskarsson}

Marine and Freshwater Research Institute, Skulagata 4,

PO Box 1390, 121 Reykjavik, Iceland

\author{
M. J. Wuenschel \\ National Oceanic and Atmospheric Administration, \\ National Marine Fisheries Service, Northeast Fisheries \\ Science Center, Woods Hole, MA 02543, USA \\ D. Lajus \\ St. Petersburg State University, \\ PO Box 199034, St. Petersburg 199034, Russia \\ C. J. G. van Damme \\ Wageningen Marine Research, PO Box 68, \\ 1970AB IJmuiden, The Netherlands \\ R. H. Bucholtz \\ National Institute of Aquatic Resources, Technical \\ University of Denmark, 2800 Kgs. Lyngby, Denmark
}


only weakly, positively related to assumingly in situ annual temperatures ( $0-30 \mathrm{~m}$ depth). Contrarily, body growth $\left(\mathrm{cm} \times \mathrm{y}^{-1}\right)$, taken as an integrator of ambient environmental conditions, closely reflected the extent of investment in reproduction. Overall, Pacific and local Norwegian herring tended to cluster based on morphometric and reproductive features, whereas oceanic Atlantic herring clustered separately. Our work underlines that herring stocks are uniquely adapted to their habitats in terms of trade-offs between fecundity and egg size whereas reproductive investment mimics the productivity of the water in question.

Keywords Herring $\cdot$ Life history $\cdot$ Fecundity $\cdot$ Egg size $\cdot$ Body size

\section{Introduction}

"Herrings" consist of a complex group of phylogenetically primitive (in the sense of being ancient) fishes (Near et al. 2012) that have been further categorized at different hierarchical levels (Cushing 1967; Iles and Sinclair 1982; Rass and Wheeler 1991). At the highest (species) level, the Atlantic (Clupea harengus) and Pacific (C. pallasii) herring (Cushing 1967) are distinguished both genetically and morphologically (Libungan et al. 2016; Lamichhaney et al. 2017). In North European waters, however, a few herring populations are genetically related to Pacific herring (Jørstad et al. 1994). This distribution is attributed to inter-oceanic migration of Pacific herring to Atlantic waters during the Pleistocene (Laakkonen et al. 2013), which led to some degree of hybridization with local Atlantic herring (Laakkonen et al. 2015).

Plasticity in life-history parameters is common within all herring stocks (Iles and Sinclair 1982; Geffen 2009). Herring show group-synchronous oocyte development (Murua et al. 2003) resulting in both species in the production of demersal/benthic eggs-either shed at once (total spawner) or in smaller portions over hours or even days (Hay 1986; Kurita et al. 2003). This very short spawning period (at the individual level) speaks for that herring can be generally considered as true capital breeder (Kurita et al. 2003). Therefore, the number of oocytes estimated just prior to spawning reflects the total realized production, as further atresia (oocyte resorption) is unlikely (Óskarsson et al. 2002). As a species, Atlantic herring spawn over the entire year, with each stock having a specific spawning season, and, as such, are frequently identified according to their specific spawning time (e.g., spring spawners and autumn spawners) and/or spawning grounds (Parrish and Saville 1965; Iles and Sinclair 1982; Sinclair and Tremblay 1984; Blaxter 1985). In contrast, Pacific herring are exclusively spring spawners, though the precise spawning time varies across their range, from mid-winter at the southern end to early summer at the extreme northern end (Blaxter 1985; Hay 1985). Egg size and fecundity differ between spawning seasons (Parrish and Saville 1965; Hempel and Blaxter 1967; van Damme et al. 2009), but egg production may also differ within the same spawning season across stocks and geographic regions (Silva et al. 2013; dos Santos Schmidt et al. 2017).

Herring stocks are also categorized by their spatial distribution and associated migratory behaviour (i.e., oceanic vs. local herring). The oceanic category contains large stock sizes that undergo long migrations, whereas the local category consists of relatively small stock sizes, which tend to be restricted to coastlines, fjords, or sea lochs (Parrish and Saville 1965; Holst et al. 2004). As the schools migrate between feeding, overwintering, and spawning areas on different spatial and seasonal scales (Lie et al. 1978; Varpe et al. 2005; Pampoulie et al. 2015), various stocks may overlap spatially (Johannessen et al. 2014; Pampoulie et al. 2015; Berg et al. 2017). Furthermore, sympatric stocks that share common feeding and overwintering areas can have different spawning seasons (Jakobsson 1980; Husebø et al. 2005; van Damme et al. 2009; dos Santos Schmidt et al. 2017). So, as suggested by McQuinn (1997) and Ware and Schweigert (2001), herring fit well within the metapopulation concept due to the high complexity of stock dynamics and structure.

Based on the above outlines, the main objective of this article is to compare variation in observed adult life-history traits of different herring stocks distributed both in the North Atlantic and Northeast Pacific Oceans. The special focus was on reproduction and associated biometrics, key attributes for evaluating stock productivity and adaptation to environmental conditions, currently represented by downloaded annual temperature data sets. Such analyses are particularly relevant today because high-latitude 
waters have significantly been warmed (IPCC 2018) since the earliest herring investigations of this kind (see below). Further these analyses underscore the need for up to date and quality assured reference points considering future climate scenarios. In this metaanalysis we collated a modern database on 26 stocks, facilitated by international cooperation across marine laboratories. The data provided a basis for contrasting quantitative information of the various herring stocks studied, according to their reproductive biology including relationships between life-history, biometrics, reproductive trade-offs and environmental conditions. Because in situ external drivers (or possible stressors under climate change), such as relevant plankton abundance or ambient temperature could not be consistently reported across stocks (following a series of pilot analyses), we used body growth as an expression of experienced living conditions (Silva et al. 2013). We aimed to consider both fecundity and egg size jointly. If such pairs did not exist, we opted for ovary size as an indicator of reproductive investment. Further, we evaluated whether historic reproductive trade-offs in Atlantic herring persist today, including corresponding data on local Norwegian and Pacific herring. Any actual changes in egg size and fecundity over time (dos Santos Schmidt et al. 2017) were not pursued further due to examples of incomplete or lacking historical time series.

\section{Material and methods}

Herring stocks and the overall approach

This work examined a series of life-history traits of adult herring females (Table 1) from 26 stocks inhabiting different regions in the Pacific and Atlantic Oceans (Fig. 1). In every case, the data were from samples taken prior to spawning but referred generally to a single season due to restricted access to reproductive time series. Examples of missing parameters are identified in Table 1. The material was grouped by geography: (1) Northeast Pacific, seven stocks off California to Alaska; (2) Northwest Atlantic, four stocks on the east coast of Canada and the US; (3) Northeast Atlantic, three stocks in central to eastern parts of the Nordic Seas, and two of the North Sea; (4) local Norwegian, eight stocks along the Norwegian coast; (5) Baltic Sea, one stock from the Central Baltic
Sea; and (6) White Sea, the White Sea stock (WSH) (Table 1). The data-rich Norwegian spring-spawning herring (NSSH) was used to exemplify the extent of annual variation in trait expression, highlighting seasons with known higher, typical, and lower fecundity levels and associated biometrics in response to varying abiotic and biotic conditions: 2007 ( $\mathrm{N}=117)$, 1999 ( $\mathrm{N}=38$ ), and 2014 (original data; dos Santos Schmidt et al. 2017) (Table 1). We also searched other databases for additional information on yearly variation in body condition because this metric impacts reproductive performance (Stearns 1992). As a result, data sets for 9 of the 26 evaluated stocks were extended by $1-2$ additional years to give an impression of body condition variability. Length-at-age is considered a more resilient factor than body condition (Sande et al. 2019), especially in slow-growing fishes, such as herring (dos Santos Schmidt et al. 2017). Consequently, any interannual dynamics in body growth were only touched upon for NSSH. This decision was supported by a wealth of existing published information on growth dynamics for both Atlantic (Dragesund et al. 1980; Nash et al. 2005; Óskarsson 2008) and Pacific herring (Tanasichuk et al. 1993; Hay et al. 2008; Ito et al. 2015), though less so for local Norwegian herring stocks (Hognestad 1994; da Silva et al. 2013; Johannessen et al. 2014) and across regions (Berg et al. 2017).

\section{Individual metrics}

Each herring was measured for length, either total length (TL, in $\mathrm{cm}$ ) or, in the case of Pacific herring, standard length (SL, in mm). Gulf of Maine autumnspawning herring $(\mathrm{GMH})$ measurements were based on fork length (FL, in $\mathrm{mm}$ ). SL and FL in centimetres were converted to TL according to Karpov and Kwiecien (1988): $\mathrm{TL}=0.766+1.223 \times \mathrm{SL}\left(r^{2}=\right.$ $0.994)$, and TL $=1.702+1.109 \times$ FL $\left(r^{2}=0.996\right)$. Whole body weight (W) was measured in grams. Age (in years) was determined from either scales or otoliths. No age data were available for NSSH in 1999. Other stocks that lacked age information included Scotia-Fundy autumn-spawning herring (SFH), Gulf of Saint Lawrence autumn-spawning herring (aGSLH), and WSH. Reproductive parameters that were indirectly calculated are marked in Table 1, but such parameters did not exist for Prince William Sound herring (PWSH). 


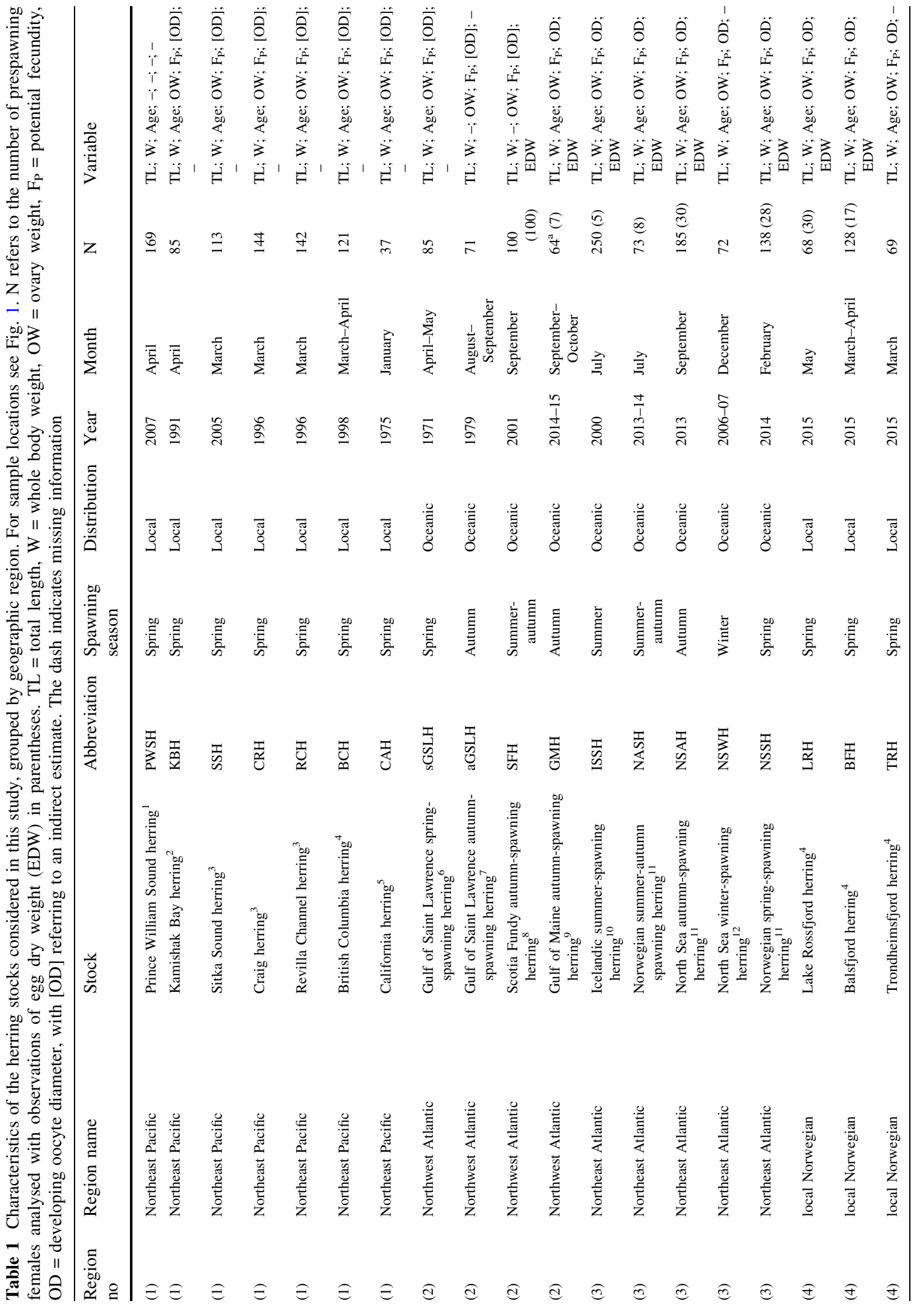




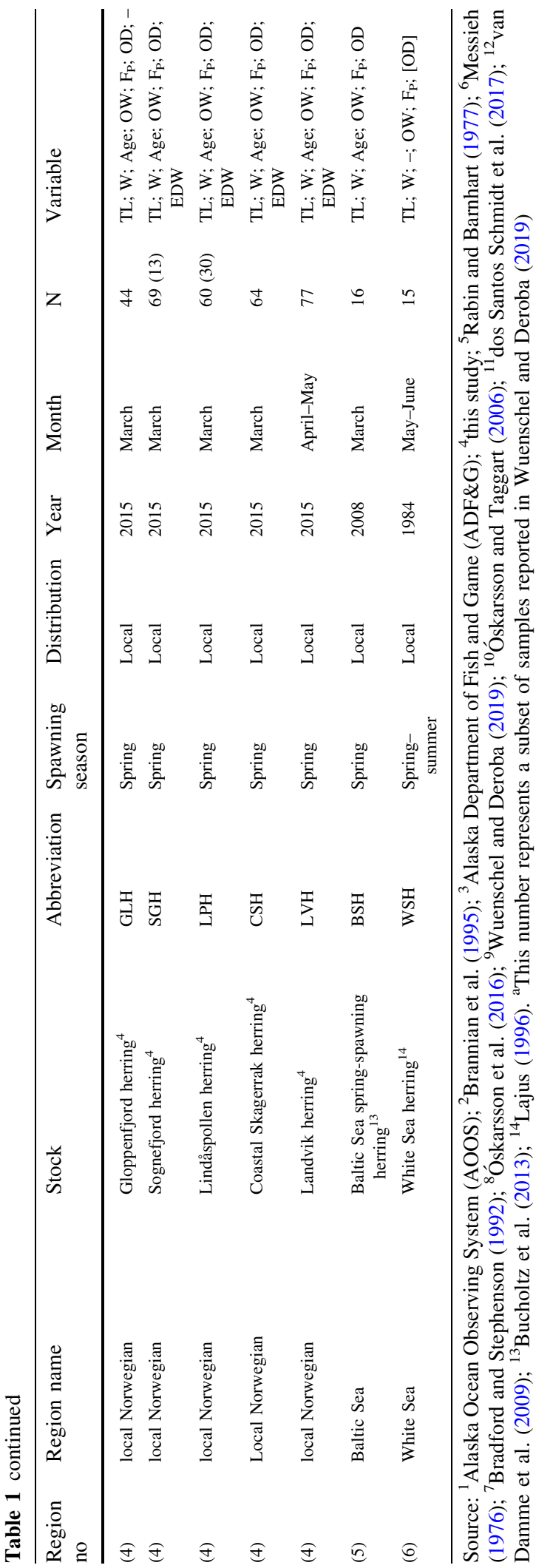

Ovary weight (OW) was determined to $0.1 \mathrm{~g}$ for Northeast Atlantic, local Norwegian herring stocks, and $\mathrm{SFH}$, where fresh ovarian subsamples were preserved in $3.6 \%$ phosphate buffered formaldehyde (Bancroft and Stevens 1996; Óskarsson et al. 2002; dos Santos Schmidt et al. 2017). Whole Baltic Sea herring (BSH) ovaries were preserved, and for North Sea winter-spawning herring (NSWH) oocytes were subsampled using a pipette, then preserved in buffered formaldehyde (van Damme et al. 2009; Bucholtz et al. 2013). GMH ovary samples were also preserved in buffered formaldehyde, but samples were either fresh or frozen prior to preserving (Wuenschel and Deroba 2019). Pacific herring stocks (except PWSH) and Gulf of Saint Lawrence spring-spawning herring (sGSLH) as well as aGSLH were preserved in Gilson's fluid (Messieh 1976; Bagenal 1978; Hay and Brett 1988). Ovaries of Sitka Sound herring (SSH) were boiled (S.C. Dressel, personal communication). The gonadosomatic index $\left(\mathrm{GSI}_{\mathrm{S}}\right.$, in \%) was calculated as: $\mathrm{GSI}_{\mathrm{S}}=100 \times \mathrm{OW} /(\mathrm{W}-\mathrm{OW})$.

Body growth analyses considered TL-at-age, fitted by the von Bertalanffy equation: $T L(t)=T_{\infty}$ $-\left(1-\mathrm{e}^{-\mathrm{k}(\mathrm{t}-\mathrm{t})}\right)$, where TL(t) refers to size at age $\mathrm{t}, \mathrm{TL}_{\infty}$ to the asymptotic value, $\mathrm{t}_{0}$ to size at age zero, and $\mathrm{k}$ to the growth coefficient $\left(\right.$ year $^{-1}$ ). Fitting of the von Bertalanffy equation and a power function were performed with the aid of R package FSA (Ogle 2016) and by standard routines, respectively. Body condition was reported as $\mathrm{W}$-at-TL, where the curve was fitted using a power function of the type $\mathrm{W}=\mathrm{a} \times \mathrm{TL}^{\mathrm{b}}$, or by Fulton's condition factor $\mathrm{K}, \mathrm{K}=100 \times \mathrm{W} / \mathrm{TL}^{3}$. Any evidence of allometric patterns $(b \neq 3)$ was specified with the listed equation (Table 2); associated plots are presented in the Supplementary Information (SI). Length dependency in $\mathrm{K}$ was added as additional information to the box plots (positive or negative correlation). Relative condition $\left(\mathrm{K}_{\mathrm{n}}\right)$ was also calculated based on the $\mathrm{W}$-at-TL curve for all stock combined $\left(a=0.003, b=3.28, r^{2}=0.905\right)$, by the formula $\mathrm{K}_{\mathrm{n}}=\mathrm{W}_{\text {observed }} / \mathrm{W}_{\text {expected }}$.

Female body growth $\left(\mathrm{cm} \times \mathrm{y}^{-1}\right)$ was individually calculated as TL-at-age/t, where ages ( $\mathrm{t}$ ) included 4,5 , and, 6 years to maximize number of across-stock comparisons (19, 20, and 22 stocks, respectively, Fig. 2). No such age-based estimations could be made for aGSLH, SFH, and WSH (Table 1), or for 4-year old NSSH and BSH, 4- and 5-year old GLH (Gloppenfjord herring), and 5-year old BFH (Balsfjord herring) 


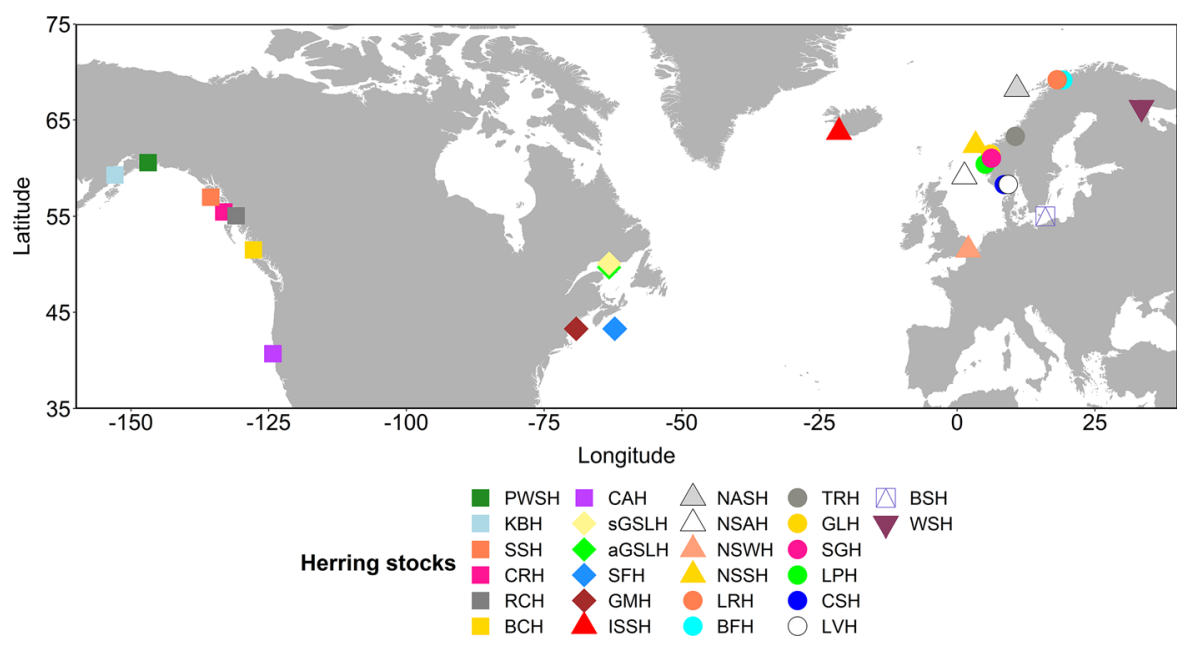

Fig. 1 Map showing the general locations of each herring stock considered in this study (for stock abbreviations, see Table 1)

(Fig. 2). Relationships between body growth, $\mathrm{F}_{\mathrm{P}}$, and OW were investigated; PWSH lacked data on $\mathrm{F}_{\mathrm{P}}$ and OW.

Reproductive analyses in the laboratory

\section{Oocyte size}

The auto-diametric method (Thorsen and Kjesbu 2001) was used to determine the mean oocyte diameter $(\mathrm{OD}$, in $\mu \mathrm{m})$ of at least 100 developing oocytes per individual for Gulf of Maine, local Norwegian, and Northeast Atlantic herring samples, except for Icelandic summer-spawning herring (ISSH), for which 50 of these oocytes were measured manually from digital images (Óskarsson and Taggart 2006). The difference in sample size did not influence measurement accuracy, which were tested on $10 \mathrm{NSSH}$ specimens $(0.416 \leq p \leq 0.976 ; \mathrm{N}=50$ vs. $\mathrm{N}=100 ;$ t-test $)$. For $\mathrm{BSH}$, oocyte diameter was estimated by the oocyte area of histological sections, corrected afterwards for shrinkage (Bucholtz et al. 2013).

Where OD data were missing, but OW and potential fecundity $\left(\mathrm{F}_{\mathrm{P}}\right.$, number of developing oocytes) data were available (Table 1), OD was given via oocyte packing density (OPD, in $\mathrm{g}^{-1}$ ). Two approaches were used to calculate the OPD. If possible, the preferred option was by using ovary subsample weights $\left(\mathrm{OW}_{\mathrm{S}}\right)$ and associated oocyte counts $\left(\mathrm{N}_{\mathrm{S}}\right)$, i.e., $\mathrm{OPD}=\mathrm{N}_{\mathrm{S}} / \mathrm{OW}_{\mathrm{S}}$, if not by using the $\mathrm{F}_{\mathrm{P}}$ value and $\mathrm{OW}$, i.e., $\mathrm{OPD}=\mathrm{F}_{\mathrm{P}} / \mathrm{OW}$. Applying the preferred option on NSSH (dos Santos Schmidt et al. 2017) resulted in the following relationship:

$$
\begin{aligned}
\mathrm{OD} & =1.48 \times 10^{4} \times \mathrm{OPD}^{-0.376}\left(r^{2}=0.96, d f\right. \\
& =23, p<0.001)
\end{aligned}
$$

The validity of this relationship was then tested with BFH and Norwegian summer-autumn spawning herring (NASH), but included a stock-specific tuning factor $(9.15 \mu \mathrm{m})$. BFH was selected due to its genetic similarity to Pacific herring (Jørstad et al. 1991), whereas NASH was selected because it spawns a few months later in the year (summer spawners) than NSSH (dos Santos Schmidt et al. 2017). Therefore, for $\mathrm{BFH}$, the OD equation became:

$\mathrm{OD}=1.48 \times 10^{4} \times \mathrm{OPD}^{-0.376}+9.15$

This revised BFH relationship was then, successfully applied to all Pacific herring stocks and WSH for the reasons abovementioned (Table 1). The validity of this relationship was also applied for SFH, a (summer)-autumn spawner, after including a stock-specific constant factor $(15.40 \mu \mathrm{m})$ :

$\mathrm{OD}=1.48 \times 10^{4} \times \mathrm{OPD}^{-0.376}+15.40$

When information on ovarian subsample weights and accompanying oocyte counts were unavailable, OPD was then determined from the $\mathrm{F}_{\mathrm{P}} / \mathrm{OW}$ relationship; this was done for California herring $(\mathrm{CAH})$, sGSLH, and aGSLH. This approach represents an indirect estimate and was calibrated using Craig 
Table 2 Weight-at-length (W-at-TL) and potential fecundity $\left(\mathrm{F}_{\mathrm{P}}\right)$-at-TL equations for the studied herring stocks. Region and stock abbreviations are shown in Table 1 . For W-at-TL, an underlined exponent reflects significant allometry $(b \neq 3)$. $\mathrm{F}_{\mathrm{P}}$ is given in absolute numbers, $\mathrm{W}$ in grams, and TL in centimetres. A dash indicates missing data. For NSSH, equations are presented for 1999, 2007, and 2014 (default)

\begin{tabular}{|c|c|c|c|c|c|c|c|}
\hline \multirow[t]{2}{*}{ Region no } & \multirow[t]{2}{*}{ Stock } & \multicolumn{3}{|l|}{ W-at-TL relationship } & \multicolumn{3}{|l|}{$\mathrm{F}_{\mathrm{P}}$-at-TL relationship } \\
\hline & & Equation & $r^{2}$ & $p$ value & Equation & $r^{2}$ & $p$ value \\
\hline (1) & PWSH & $\mathrm{W}=0.59 \times 10^{-2} \times \mathrm{TL}^{3.043}$ & 0.903 & $<0.001$ & - & - & - \\
\hline (1) & $\mathrm{KBH}$ & $\mathrm{W}=0.72 \times 10^{-3} \times \mathrm{TL}^{3.684}$ & 0.957 & $<0.001$ & $\mathrm{~F}_{\mathrm{P}}=4.26 \times 10^{-5} \times \mathrm{TL}^{3.954}$ & 0.828 & $<0.001$ \\
\hline (1) & $\mathrm{SSH}$ & $\mathrm{W}=0.24 \times 10^{-2} \times \mathrm{TL}^{\overline{3.306}}$ & 0.892 & $<0.001$ & $\mathrm{~F}_{\mathrm{P}}=1.77 \times 10^{-4} \times \mathrm{TL}^{3.562}$ & 0.653 & $<0.001$ \\
\hline (1) & $\mathrm{CRH}$ & $\mathrm{W}=0.94 \times 10^{-3} \times \mathrm{TL}^{3.573}$ & 0.940 & $<0.001$ & $\mathrm{~F}_{\mathrm{P}}=1.28 \times 10^{-4} \times \mathrm{TL}^{3.685}$ & 0.770 & $<0.001$ \\
\hline (1) & $\mathrm{RCH}$ & $\mathrm{W}=0.33 \times 10^{-2} \times \mathrm{TL}^{3.214}$ & 0.937 & $<0.001$ & $\mathrm{~F}_{\mathrm{P}}=2.86 \times 10^{-4} \times \mathrm{TL}^{3.455}$ & 0.783 & $<0.001$ \\
\hline (1) & $\mathrm{BCH}$ & $\mathrm{W}=0.018 \times \mathrm{TL}^{2.758}$ & 0.828 & $<0.001$ & $\mathrm{~F}_{\mathrm{P}}=1.42 \times 10^{-3} \times \mathrm{TL}^{3.065}$ & 0.649 & $<0.001$ \\
\hline (1) & $\mathrm{CAH}$ & $\mathrm{W}=0.41 \times 10^{-2} \times \mathrm{TL}^{3.288}$ & 0.963 & $<0.001$ & $\mathrm{~F}_{\mathrm{P}}=5.33 \times 10^{-4} \times \mathrm{TL}^{3.458}$ & 0.939 & $<0.001$ \\
\hline (2) & sGSLH & $\mathrm{W}=0.011 \times \mathrm{TL}^{2.903}$ & 0.826 & $<0.001$ & $\mathrm{~F}_{\mathrm{P}}=2.14 \times 10^{-1} \times \mathrm{TL}^{1.669}$ & 0.093 & 0.005 \\
\hline (2) & aGSLH & $\mathrm{W}=0.012 \times \mathrm{TL}^{2.936}$ & 0.839 & $<0.001$ & $\mathrm{~F}_{\mathrm{P}}=8.35 \times 10^{-2} \times \mathrm{TL}^{2.069}$ & 0.168 & $<0.001$ \\
\hline (2) & SFH & $\mathrm{W}=0.19 \times 10^{-2} \times \mathrm{TL}^{3.454}$ & 0.963 & $<0.001$ & $\mathrm{~F}_{\mathrm{P}}=4.05 \times 10^{-6} \times \mathrm{TL}^{4.991}$ & 0.897 & $<0.001$ \\
\hline (2) & GMH & $\mathrm{W}=0.008 \times \mathrm{TL}^{3.018}$ & 0.807 & $<0.001$ & $\mathrm{~F}_{\mathrm{P}}=7.30 \times 10^{-5} \times \mathrm{TL}^{4.005}$ & 0.622 & $<0.001$ \\
\hline (3) & ISSH & $\mathrm{W}=0.97 \times 10^{-2} \times \mathrm{TL}^{2.996}$ & 0.922 & $<0.001$ & $\mathrm{~F}_{\mathrm{P}}=1.30 \times 10^{-5} \times \mathrm{TL}^{4.518}$ & 0.761 & $<0.001$ \\
\hline (3) & NASH & $\mathrm{W}=0.047 \times \mathrm{TL}^{2.539}$ & 0.841 & $<0.001$ & $\mathrm{~F}_{\mathrm{P}}=1.96 \times 10^{-5} \times \mathrm{TL}^{4.334}$ & 0.316 & $<0.001$ \\
\hline (3) & NSAH & $\mathrm{W}=0.048 \times \mathrm{TL}^{\overline{2.524}}$ & 0.660 & $<0.001$ & $\mathrm{~F}_{\mathrm{P}}=6.97 \times 10^{-5} \times \mathrm{TL}^{3.885}$ & 0.208 & $<0.001$ \\
\hline (3) & NSWH & $\mathrm{W}=0.004 \times \mathrm{TL}^{3.209}$ & 0.806 & $<0.001$ & $\mathrm{~F}_{\mathrm{P}}=1.19 \times 10^{-3} \times \mathrm{TL}^{2.997}$ & 0.164 & 0.014 \\
\hline (3) & NSSH & $\mathrm{W}=0.050 \times \mathrm{TL}^{2.478}$ & 0.614 & $<0.001$ & $\mathrm{~F}_{\mathrm{P}}=8.11 \times 10^{-3} \times \mathrm{TL}^{2.332}$ & 0.063 & 0.003 \\
\hline (3) & NSSH (2007) & $\mathrm{W}=0.11 \times 10^{-2} \times \mathrm{TL}^{3.557}$ & 0.893 & $<0.001$ & $\mathrm{~F}_{\mathrm{P}}=1.26 \times 10^{-7} \times \mathrm{TL}^{5.641}$ & 0.694 & $<0.001$ \\
\hline (3) & NSSH (1999) & $\mathrm{W}=0.013 \times \mathrm{TL}^{2.841}$ & 0.691 & $<0.001$ & $\mathrm{~F}_{\mathrm{P}}=1.02 \times 10^{-3} \times \mathrm{TL}^{2.965}$ & 0.318 & $<0.001$ \\
\hline (4) & LRH & $\mathrm{W}=0.453 \times \mathrm{TL}^{1.610}$ & 0.668 & $<0.001$ & $\mathrm{~F}_{\mathrm{P}}=1.43 \times 10^{-1} \times \mathrm{TL}^{1.331}$ & 0.036 & 0.123 \\
\hline (4) & $\mathrm{BFH}$ & $\mathrm{W}=0.035 \times \mathrm{TL}^{\overline{2.529}}$ & 0.892 & $<0.001$ & $\mathrm{~F}_{\mathrm{P}}=5.96 \times 10^{-4} \times \mathrm{TL}^{3.197}$ & 0.770 & $<0.001$ \\
\hline (4) & $\mathrm{TRH}$ & $\mathrm{W}=0.014 \times \mathrm{TL}^{2.822}$ & 0.610 & $<0.001$ & $\mathrm{~F}_{\mathrm{P}}=2.61 \times 10^{-2} \times \mathrm{TL}^{2.037}$ & 0.017 & 0.285 \\
\hline (4) & GLH & $\mathrm{W}=0.95 \times 10^{-2} \times \mathrm{TL}^{2.926}$ & 0.802 & $<0.001$ & $\mathrm{~F}_{\mathrm{P}}=1.67 \times 10^{-2} \times \mathrm{TL}^{2.242}$ & 0.313 & $<0.001$ \\
\hline (4) & SGH & $\mathrm{W}=0.42 \times 10^{-2} \times \mathrm{TL}^{3.159}$ & 0.825 & $<0.001$ & $\mathrm{~F}_{\mathrm{P}}=7.50 \times 10^{-3} \times \mathrm{TL}^{2.359}$ & 0.093 & 0.011 \\
\hline (4) & LPH & $\mathrm{W}=0.13 \times \mathrm{TL}^{2.216}$ & 0.567 & $<0.001$ & $\mathrm{~F}_{\mathrm{P}}=2.82 \times \mathrm{TL}^{0.700}$ & 0.009 & 0.492 \\
\hline (4) & $\mathrm{CSH}$ & $\mathrm{W}=0.32 \times 10^{-2} \times \mathrm{TL}^{3.243}$ & 0.772 & $<0.001$ & $\mathrm{~F}_{\mathrm{P}}=1.70 \times 10^{-4} \times \mathrm{TL}^{3.445}$ & 0.163 & $<0.001$ \\
\hline (4) & $\mathrm{LVH}$ & $\mathrm{W}=0.058 \times \mathrm{TL}^{2.413}$ & 0.712 & $<0.001$ & $\mathrm{~F}_{\mathrm{P}}=5.44 \times 10^{-3} \times \mathrm{TL}^{2.505}$ & 0.066 & 0.024 \\
\hline (5) & BSH & $\mathrm{W}=0.009 \times \mathrm{TL}^{\overline{2.890}}$ & 0.964 & $<0.001$ & $\mathrm{~F}_{\mathrm{P}}=4.30 \times 10^{-4} \times \mathrm{TL}^{3.651}$ & 0.848 & $<0.001$ \\
\hline (6) & WSH & $\mathrm{W}=0.22 \times 10^{-2} \times \mathrm{TL}^{3.380}$ & 0.931 & $<0.001$ & $\mathrm{~F}_{\mathrm{P}}=4.82 \times 10^{-4} \times \mathrm{TL}^{3.358}$ & 0.735 & $<0.001$ \\
\hline
\end{tabular}

herring $(\mathrm{CRH})$, where each individual fecundity estimate was based on five replicates. Thereafter, the OD of sGSLH, CAH, and aGSLH was determined by Eqs. 1, 2, or 3, respectively. As OPD and OD are strongly related, all ODs were considered accurate and used in all further analyses.

\section{Fecundity}

Potential fecundity for Northeast Atlantic (except NSWH) and local Norwegian herring stocks were estimated by OPD (Thorsen and Kjesbu 2001; Kurita and Kjesbu 2009): $\quad \mathrm{F}_{\mathrm{P}}=\mathrm{OW} \times 7.474 \times 10^{10}$ $\times \mathrm{OD}^{-2.584}\left(r^{2}=0.96, d f=23, p<0.001\right)(\mathrm{dos}$ Santos Schmidt et al. 2017). This equation was equally suitable for NASH and applied for SFH and GMH (see above). "The volumetric method" was used for SSH (S.C. Dressel, personal communication), i.e., $F_{P}$ was defined as $\mathrm{N}_{\mathrm{S}} \times \mathrm{OV} / \mathrm{OV}_{\mathrm{S}}$, where $\mathrm{OV}$ is ovary volume and $\mathrm{OV}_{\mathrm{S}}$ ovary subsample volume (Bagenal 1978), whereas stereological techniques provided fecundity estimates for BSH (Bucholtz et al. 2013). The 
Northeast Pacific
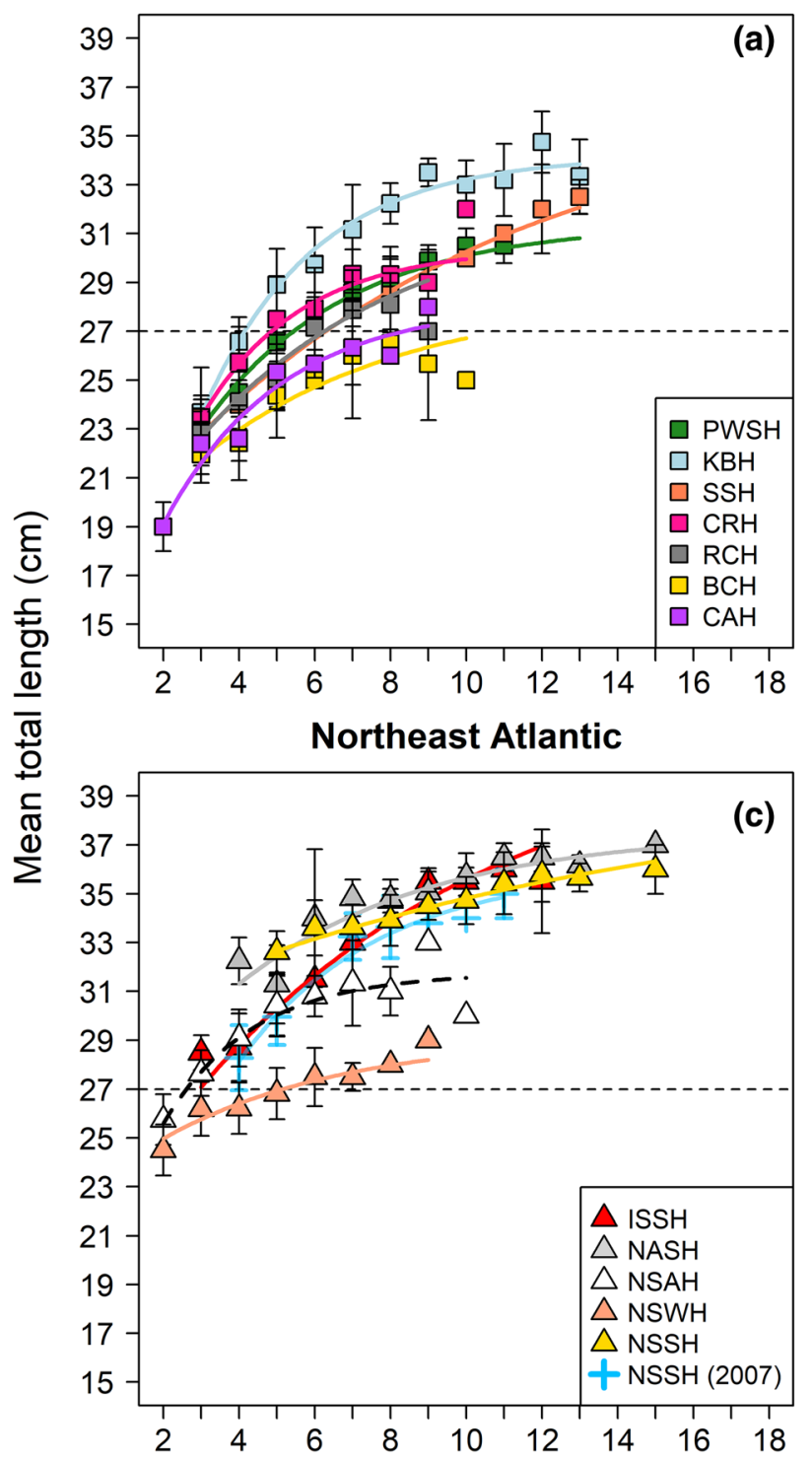

Northwest Atlantic
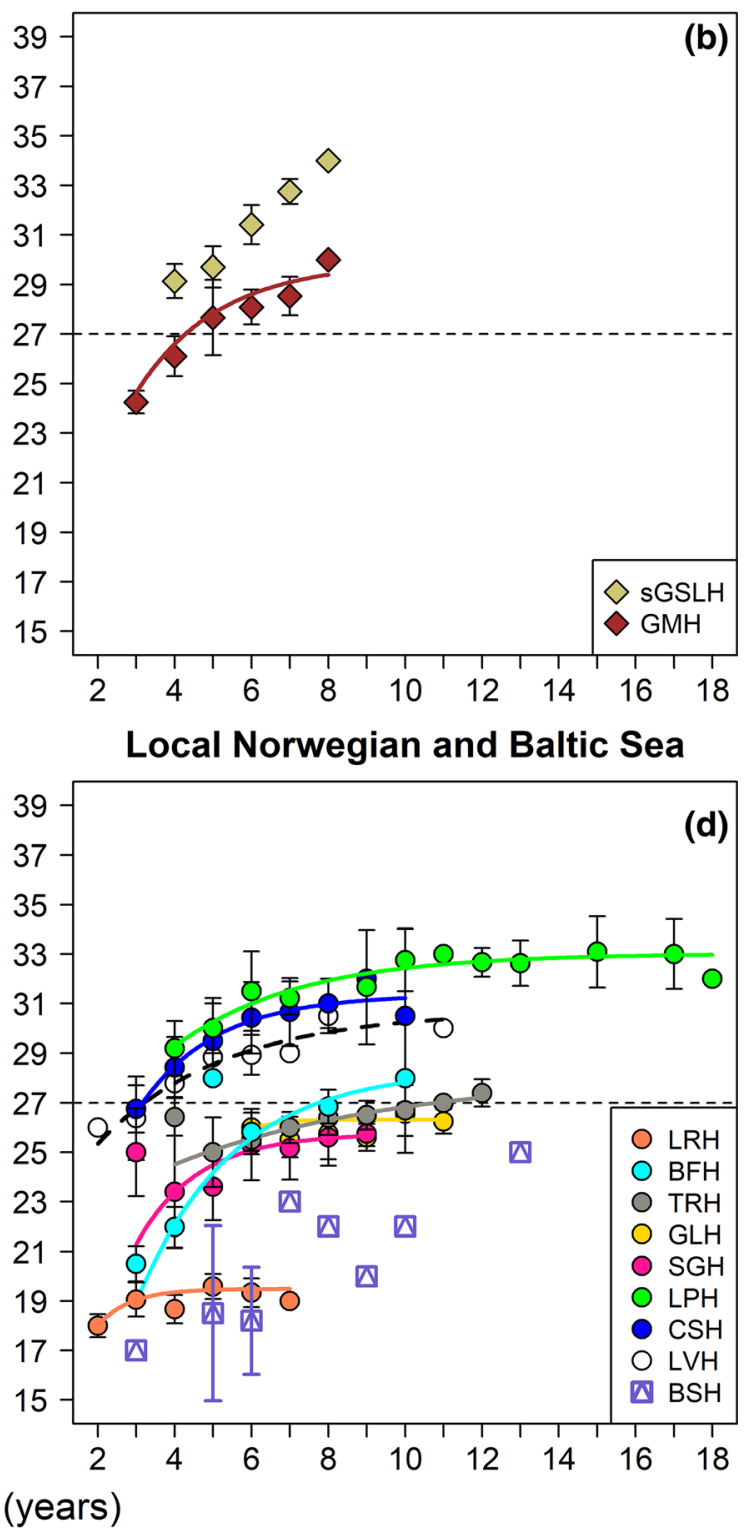

reference line is $27 \mathrm{~cm}$. Growth data for SFH, aGSLH, and WSH are missing due to a lack of age data. For NSSH, both 2007 and 2014 (default) data are included. Within each region, stocks are sorted by main place attachment, from north (top) to south

(amount of connective tissue and blood vessels) was ignored in accordance with standard practice (Buzeta and Waiwood 1982; Hay and Brett 1988). 
Egg dry weight

Egg dry weight (EDW, in $\mu \mathrm{g}$ ) was reported based on analyses of hydrated oocytes of specimens belonging to Northwest Atlantic, Northeast Atlantic, and local Norwegian herring stocks (Table 1). The use of hydrated instead of postovulated oocytes (eggs) was considered adequate (Kurita et al. 2003) and reduced the risk of losing any eggs (and underestimating fecundity). For SFH and ISSH, triplicates of 10 fresh eggs were dried at $62{ }^{\circ} \mathrm{C}$ for $48 \mathrm{~h}$ and placed in a desiccator for a further $24 \mathrm{~h}$ (Óskarsson et al. 2019). The rest of the herring stocks samples had been fixed in formalin; prefixation has been shown to not influence EDW (Hempel and Blaxter 1967; dos Santos Schmidt et al. 2017). A single sample of 50 formalinfixed eggs per female were dried at $60{ }^{\circ} \mathrm{C}$ for 3 days (dos Santos Schmidt et al. 2017), except for GMH, where two or three replicates contained 50 eggs were used, when the eggs dissociation was difficult a total of 25 eggs were used instead. Differences in egg dry weight procedures (Hislop and Bell 1987; Kjesbu et al. 1996) were considered but found to be insignificant for the present analyses.

\section{Oocyte wet weight and egg water content}

Mean oocyte wet weight (OoW, in $\mathrm{mg}$ ) was given as: $\mathrm{OoW}=1000 \times \mathrm{OW} / \mathrm{F}_{\mathrm{P}}$. This estimate included ovarian stroma. The corresponding water content (in \%) was: $100-100 \times$ EDW/OoW, marked as STEP 1 . The following estimations were restricted to NSSH, verified from earlier proximate analyses to show an egg water content of typically $70 \%$ (Kurita et al. 2003). OoW was multiplied with IF (interaction factor; IF < 1.0); this resulting correction was applied to the 2014 NSSH data set, marked as STEP 2.

\section{Reproductive investment}

Reproductive investment (RI, in $\mathrm{mg}$ ) was derived from multiplying egg mass by the number of eggs: $\mathrm{RI}=\mathrm{EDW} \times \mathrm{F}_{\mathrm{P}}$. This was followed by standardization by body mass, creating an index for reproductive investment $\left(\mathrm{RII}_{\mathrm{S}}\right)$ : $\mathrm{RII}_{\mathrm{S}}=\mathrm{RI} / \mathrm{W}_{\mathrm{S}}\left(\mathrm{mg} \mathrm{g}^{-1}\right)$, where $\mathrm{W}_{\mathrm{S}}$ is ovary-free (somatic) weight (dos Santos Schmidt et al. 2017). Finally, as EDW was missing for several stocks (Table 1), OW was used as a proxy for reproductive investment.
In situ temperatures

Temperature data were extracted from the NOAA World Ocean Atlas (WOA2018) (https://www.nodc. noaa.gov/access/index.html) to represent, as far as possible, the encountered thermal conditions for the various herring stocks. WOA2018 contains objectively analysed climatological fields of in situ temperatures and other physical and chemical variables at standard depths for various periods (Garcia et al. 2019). Decadal averaged annual temperatures, from two discrete depths $(0$ and $30 \mathrm{~m})$ were extracted for each of the 26 areas where the herring stocks are found (Fig. 1; Table S1). The time of sampling/observation for the 26 herring stocks (Table 1) varied from the 1970s (CAH, sGSLH, aGSLH) to the recent decade for the Northeast Atlantic herring, except WSH, which was sampled in 1984. Due to low resolution of temperature data in WOA2018 from the White Sea we selected data from https://www.nodc.noaa.gov/OC5/ WH_SEA/index1.html that provide annual temperature data for the specific sampling year 1984. We assigned the decadal averaged temperature that overlaps with the biological data of the herring stocks (Table S1).

The habitat extents of herring stocks vary interannually and seasonally (e.g. Dragesund et al. 1997) but are typically not exactly known, or, in cases, indicative only. In regions with small spatial temperature gradients the differences between the tabulated temperature values and the actual ambient herring temperature can be assumed small. However, in regions where vertical and/or horizontal temperature gradients are large, the actual ambient temperatures might be quite different from the tabulated ones. Therefore, we excluded the two herring stocks in the Gulf of Saint Lawrence, aGSLH and sGSLH. Not only because of the strong vertical temperature gradients seen in this region (Table S1), causing estimates of ambient temperature to be sensitive to the depth position of the herring, but also because these stocks seasonally leave the cool Gulf of Saint Lawrence entering the warmer open ocean (Comeau et al. 2002) requiring detailed knowledge about migration routes as well. Note here that also BSH and WSH stay in waters with strong temperature gradients (Table S1). 
Statistical analysis

All plots and statistical analyses were performed in $\mathrm{R}$ (version 3.5.2; R Core Team 2017). Biometric and reproductive parameters were tested for normality (Shapiro-Wilk test). As this assumption often did not hold, the non-parametric Kruskal-Wallis test was then used instead of parametric tests (ANOVA, t-test) when contrasting stocks. Analysis of covariance (ANCOVA) was applied to body growth (TL-at-age) and body condition (W-at-TL) data following log transformation. ANOVA was used to test difference between temperature and condition (Fulton's $\mathrm{K}$ and relative condition), due the differences in number of observations for herring stocks (Table 1) the weighting factor was included in the model. Post-hoc pairwise comparisons were made using Tukey's honest significant-differences (HSD) test $(p>0.05)$. As the spatial configuration was known a priori (Zuur et al. 2007) (Table 1), discriminant analysis (package vegan; Oksanen et al. 2016) was used to differentiate between herring stocks based on either their biometric (TL, W, and, age) or reproductive ( $\mathrm{OD}$ and $\mathrm{RF}_{\mathrm{P}, \mathrm{TL}}{ }^{3}$ ) parameters, but also, as supplementary information, a combination of these two trait categories (TL, W, age, OD, and $\mathrm{RF}_{\mathrm{P}, \mathrm{TL}}{ }^{3}$ ). A MANOVA (the Wilks lambda) test was applied to verify overall group effect significance (Zuur et al. 2007). A subset of 150 of 250 collected specimens of ISSH was randomly selected to maintain a comparable amount of data across stocks (Table 1).

\section{Results}

The physical setting of herring stocks

The Northeast Pacific and North Atlantic herring are largely confined to boreal ecosystems with $\mathrm{CAH}$ at the upper thermal habitat range of about $13{ }^{\circ} \mathrm{C}$ (with the annual mean as reference) associated with Californian upwelling ecosystem, and WSH of the lower thermal habitat range of less than $4{ }^{\circ} \mathrm{C}$ associated with ecosystems close the Arctic (Fig. 1; Table S1). The spatial extent of the stocks reflects the spatial structure of the ocean climate in the various regions: (1) the Northeast Pacific herring stocks were distributed along a $3000 \mathrm{~km}$ coastline from around Cape Mendocino at the Californian coast to Shelikof Strait in Alaska over which distance the annual mean ambient temperature changes from 13 to $6{ }^{\circ} \mathrm{C}$ (Table S1); (2) the Northwest Atlantic herring stocks differ in spatial distribution from the other groups of herring stocks, because of the extraordinary strong latitudinal thermal gradient along the Canadian east coast where the cold southwardflowing Labrador Current encounters the warm northward-flowing Gulf Stream (Sundby 2000; Sundby and Drinkwater 2007). Here, the distributions of the herring stocks are limited from the Bay of Fundy to the northern Gulf of Saint Lawrence, a distance of only $1200 \mathrm{~km}$, but where annual mean ambient temperature changes from 10 to $4{ }^{\circ} \mathrm{C}$ in the upper layers (Table S1), and 3) The Northeast Atlantic stocks, including the Icelandic stock, are distributed along a $4000 \mathrm{~km}$ distance from the English Channel to the White Sea over which distance the ambient temperature changes from 12 to less than $4{ }^{\circ} \mathrm{C}$ (Table S1).

The herring stocks are latitudinally distributed from $40^{\circ} \mathrm{N}(\mathrm{CAH})$ to $70^{\circ} \mathrm{N}$ (BFH) (cf. Fig. 1) implying that they all are confined to spring-bloom ecosystems with increasing seasonality in the primary production with increasing latitude, and where the increasing seasonality has a particular influence on life-cycle dynamics of planktivorous species when exceeding "critical latitude" near the Arctic Circle (Sundby et al. 2016). Here, primary production during winter is too low to sustain active feeding leading to dominating overwintering strategy for herbivorous zooplankton with cascading effect on planktivorous fish. These processes are relevant for the northernmost stocks of the Northeast Atlantic.

Biometrics by stock and region

\section{Analysis of body growth}

Prespawning females of Northeast Atlantic herring, except for NSAH (North Sea autumn-spawning herring) and NSWH, were larger than local Norwegian and Northeast Pacific herring ( $\geq 26 \mathrm{~cm}$ vs. $\geq 18-19$ cm) (Fig. 2a, c, d). The TL-at-age curves overlapped frequently across regions (Fig. 2). Northeast Pacific herring grew from 19 to $35 \mathrm{~cm}$ between 2 and 13 years of age, with Kamishak Bay herring (KBH) exhibiting the fastest growth and British Columbia $(\mathrm{BCH})$ and $\mathrm{CAH}$ the slowest (Fig. 2). The regional $\mathrm{TL}_{\infty}$ ranged from $28.16(\mathrm{CAH})$ to $36.72 \mathrm{~cm}$ (SSH) (Table 3). sGSLH apparently grew relatively faster than GMH (Fig. 2b), though $\mathrm{TL}_{\infty}$ of sGSLH was uncertain 
whereas settled at $29.92 \mathrm{~cm}$ for GMH (Table 3). Northeast Atlantic herring were $26-37 \mathrm{~cm}$ at 2-15 years of age, except for NSAH, in which the curve flattened out relatively quickly, noting 10 years and $31 \mathrm{~cm}$ as the maxima (Fig. 2c). The corresponding von Bertalanffy parameters indicated a latitudinal trend in the Northeast Atlantic herring stocks, with the northern herring stocks (ISSH, NSSH, and NASH) showing the largest $\mathrm{TL}_{\infty}$ and smaller growth coefficient compared to the southern herring stocks (NSAH and NWSH) (Table 3). Local Norwegian herring had comparable values to Northeast Pacific herring: $18-33 \mathrm{~cm}$ for $2-12$ years of age. The examined material for Lindåspollene herring (LPH) included older fish (13-18 years) and none of the Lake Rossfjord herring (LRH) females exceeded 7 years (Fig. 2d); these two stocks span extreme situations. LRH showed the highest growth coefficient compared to other local Norwegian herring stocks, except possibly GLH (Table 3 ). BSH had similar length-atage as LRH at younger ages (3-6 years) but varied considerably at older ages ( 7 to 13 years) (Fig. 2), this large variation may be related to the lower number of observations (Table 1).

In line with the above results, both TL and age varied significantly across stocks (Kruskal-Wallis test; $p<0.001$ for both variables). In addition, the corresponding TL-at-age was different (ANCOVA; slope and intercept: $p<0.001)$. For local Norwegian herring, southern stocks (Landvik herring [LVH], Coastal Skagerrak [CSH], and LPH) grew faster and became larger than those located either partly or more clearly northwards (Sognefjord [SGH], GLH, Trondheimsfjord [TRH], and BFH) (Fig. 2d). LRH, found geographically near BFH (Fig. 1), formed a third, much slower growing category (Fig. 2d). The sensitivity analysis on NSSH (2007 vs. 2014; Fig. 2c) showed interannual variation in growth (ANCOVA; slope and intercept: $p<0.001$ ) but was minor compared to the variation among stocks, both within and between regions (Fig. 2).

\section{Analysis of body condition}

Body condition (W-at-TL) varied among the 26 herring stocks (ANCOVA: slope and intercept: $p<0.001$ ) (Fig. S1), considering here also detailed a posteriori comparison (Table S2). Any detected nuance in curve appearance was also significant, as tested in NSSH (ANCOVA: slope and intercept: $p<0.001$ ) (Fig. S1c). W and TL were undoubtedly related $\left(r^{2} \geq 0.559, p<0.001\right)$ (Table 2$)$. For Northeast Pacific herring, higher $\mathrm{W}$-at-TL values were found further south (Fig. S1a), indicating a latitudinal trend in body condition in an opposite direction as the one for body growth (Fig. 2a). Thus, CAH appeared to be in the best condition, followed by $\mathrm{BCH}$ and the investigated stocks of Alaska herring (PWSH, KBH, $\mathrm{SSH}, \mathrm{CRH}$, and Revilla Channel herring $[\mathrm{RCH}]$ ), with the latter five showing overlapping patterns (Fig. S1a). Overlapping W-at-TL curves were also seen among Northeast Atlantic herring stocks, except for NSSH, which had lower values (Fig. S1c). For local Norwegian herring, LPH stood out positively $(p<0.05$; Fig. S1d). The curve of WSH fell at the midpoint for local Norwegian herring (Fig. S1d). In the Northwest Atlantic, autumn spawners in the Gulf of Saint Lawrence (aGSLH) appeared stouter than the complementary spring spawners (sGSLH) (Fig. S1b). $\mathrm{SFH}$, the other examined category of autumn spawners in this region, overlapped with aGSLH at similar TLs (Fig. S1b). Studying all functional relationships presently established between $\mathrm{W}$ and TL, the exponent b ranged from 1.61 for LRH to 3.68 for $\mathrm{KBH}$ (Table 2). Local Norwegian herring had the highest variation in $b$ across stocks (Table 2). Grand mean b for all 26 stocks was 2.93. Thus, the use of Fulton's condition factor K, in which $b$ is set at 3 (isometric growth), seemed reasonable, though many stocks had $b$ values either significantly below 3 (8 stocks) or above 3 (8 stocks; Table 2).

The following analyses of $\mathrm{K}$ strengthened the above findings based on $\mathrm{W}$-at-TL, but also clarified that herring condition often exhibits length dependency, either positive or negative (correlation analysis; $p>0.05$ ) (Fig. 3). This dependency could switch sign between seasons (cf. NSSH). Herring females from the Northeast Pacific and along the Norwegian coast up to the White Sea typically had $\mathrm{K}<0.8$, whereas $\mathrm{K}>0.8$ for those from the Northwest and Northeast Atlantic (Fig. 3). Notable exceptions to these regional patterns were $\mathrm{CAH}$ (fatter), $\mathrm{NSSH}$ (thinner), and LPH (fatter) (Fig. 3). Interannual variation in $\mathrm{K}$ was, as expected, observed; $\mathrm{K}$ for NSSH and NSAH fluctuated significantly (ANOVA; $p<0.001$ and $p=0.015$, respectively). The other stocks tested also indicated that $\mathrm{K}$ is highly dynamic ( $p \leq 0.039$; 9 stocks) (Fig. 3). However, these fluctuations in $\mathrm{K}$ for 
Table 3 von Bertalanffy parameters output, asymptotic length $\left(\mathrm{TL}_{\infty}\right)$, and growth coefficient $(\mathrm{k})$ for each herring stocks. Growth curves are presented in Fig. 2. Herring stocks with insufficient or missing data are also indicated (dashed line; for further details check Table 1 and/or Fig. 2). LCI refers to the lower confidence value, UCI, the upper confidence interval, and $\mathrm{SE}$ is the standard error

\begin{tabular}{|c|c|c|c|c|c|c|c|c|c|c|c|c|c|}
\hline Region no & Stock & $\mathrm{TL}_{\infty}$ & $\begin{array}{l}\text { LCI } \\
\left(\mathrm{TL}_{\infty}\right)\end{array}$ & $\begin{array}{l}\text { UCI } \\
\left(\mathrm{TL}_{\infty}\right)\end{array}$ & SE & $t_{0}$ & LCI $\left(\mathrm{t}_{0}\right)$ & $\begin{array}{l}\mathrm{UCI} \\
\left(\mathrm{t}_{0}\right)\end{array}$ & SE & $\mathrm{k}$ & $\begin{array}{l}\text { LCI } \\
(\mathrm{k})\end{array}$ & $\begin{array}{l}\text { UCI } \\
(\mathrm{k})\end{array}$ & $\mathrm{SE}$ \\
\hline (1) & PWSH & 31.4 & 30.48 & 33.48 & 0.68 & -1.96 & -3.92 & -0.95 & 0.70 & 0.27 & 0.17 & 0.34 & 0.05 \\
\hline (1) & $\mathrm{KBH}$ & 34.2 & 33.56 & 35.23 & 0.41 & -0.43 & -1.30 & 0.23 & 0.39 & 0.34 & 0.27 & 0.41 & 0.04 \\
\hline (1) & $\mathrm{SSH}$ & 36.72 & 32.89 & 49.05 & 3.08 & -5.82 & -10.91 & -2.84 & 2.05 & 0.11 & 0.05 & 0.19 & 0.04 \\
\hline (1) & $\mathrm{CRH}$ & 30.46 & 29.41 & 32.26 & 0.64 & -0.88 & -2.54 & 0.20 & -0.88 & 0.38 & 0.23 & 0.55 & 0.08 \\
\hline (1) & $\mathrm{RCH}$ & 32.26 & 29.05 & 42.74 & 3.07 & -3.55 & -7.89 & -1.20 & 1.98 & 0.18 & 0.07 & 0.36 & 0.09 \\
\hline (1) & $\mathrm{BCH}$ & 28.48 & 25.68 & 40.19 & 2.85 & -4.6 & -12.10 & -1.35 & 3.25 & 0.19 & 0.06 & 0.43 & 0.12 \\
\hline (1) & $\mathrm{CAH}$ & 28.16 & 26.86 & 30.84 & 1.10 & -1.5 & -2.96 & -0.60 & 0.74 & 0.32 & 0.21 & 0.45 & 0.09 \\
\hline (2) & sGSLH & - & - & - & - & - & - & - & - & - & - & - & - \\
\hline (2) & aGSLH & - & - & - & - & - & - & - & - & - & - & - & - \\
\hline (2) & SFH & - & - & - & - & - & - & - & - & - & - & - & - \\
\hline (2) & GMH & 29.92 & 29.18 & 31.19 & 0.51 & -0.73 & -3.31 & 0.41 & 0.79 & 0.46 & 0.26 & 0.67 & 0.11 \\
\hline (3) & ISSH & 41.72 & 37.41 & 51.88 & 3.09 & -5.42 & -10.11 & -2.52 & 1.80 & 0.12 & 0.06 & 0.22 & 0.04 \\
\hline (3) & NASH & 37.58 & 36.34 & 41.84 & 1.03 & -5.02 & -15.71 & -1.52 & 2.70 & 0.2 & 0.08 & 0.34 & 0.07 \\
\hline (3) & NSAH & 31.76 & 31.05 & 33.83 & 0.54 & -1.87 & -4.12 & -1.00 & 0.68 & 0.42 & 0.25 & 0.55 & 0.54 \\
\hline (3) & NSSH & 39.81 & 36.18 & 46.15 & 5.12 & -18.82 & -33.98 & -6.09 & 13.92 & 0.07 & 0.03 & 0.21 & 0.07 \\
\hline (3) & NSWH & 29.17 & 27.34 & 34.71 & 2.33 & -7.27 & -16.37 & -1.14 & 6.38 & 0.21 & 0.07 & 0.67 & 0.19 \\
\hline (4) & LRH & 19.49 & 19.27 & 19.86 & 0.17 & -0.16 & -1.99 & 0.93 & 0.74 & 1.19 & 0.63 & 2.39 & 0.42 \\
\hline (4) & $\mathrm{BFH}$ & 28.38 & 27.52 & 30.18 & 0.67 & 0.29 & -0.83 & 1.01 & 0.52 & 0.41 & 0.27 & 0.53 & 0.08 \\
\hline (4) & $\mathrm{TRH}$ & 28.16 & 26.82 & 32.80 & 1.96 & -8.1 & -23.85 & 0.07 & 11.77 & 0.17 & 0.05 & 0.51 & 0.19 \\
\hline (4) & GLH & 26.32 & - & - & - & 3.74 & - & - & - & 1.95 & - & - & - \\
\hline (4) & $\mathrm{SGH}$ & 25.75 & 25.00 & 31.66 & 0.36 & 0.22 & -14.31 & 2.93 & 2.58 & 0.63 & 0.08 & 2.44 & 0.11 \\
\hline (4) & LPH & 33.02 & - & - & - & -3.02 & - & - & - & 0.31 & - & - & - \\
\hline (4) & $\mathrm{CSH}$ & 31.36 & 30.33 & 33.98 & 0.76 & -0.77 & -5.22 & 1.06 & 1.57 & 0.5 & 0.18 & 1.04 & 0.22 \\
\hline (4) & LVH & 30.69 & 29.24 & 36.48 & 1.17 & -3.7 & -12.00 & -0.68 & 2.40 & 0.31 & 0.09 & 0.67 & 0.14 \\
\hline (5) & $\mathrm{BSH}$ & - & - & - & - & - & - & - & - & - & - & - & - \\
\hline (6) & WSH & - & - & - & - & - & - & - & - & - & - & - & - \\
\hline
\end{tabular}

each stock were restricted and did not change the general regional and stock-specific patterns. To cancel out any bias attributed to length dependency, $K_{n}$ outputs were also examined finding comparable pattern as outlined for $\mathrm{K}$ : a negative latitudinal trend for Pacific herring and Northwest Atlantic herring (provided restricted to autumn spawners), a positive trend for Northeast Atlantic herring, and a slightly flat average for local Norwegian herring stocks (Fig. S2).

\section{Biometric discriminant analysis}

The separational effect of TL, $\mathrm{W}$, and age resulted in a tilted U-shaped plot in which smaller-sized Northeast Pacific, local Norwegian and Baltic Sea herring stocks clustered, whereas larger-sized local Norwegian herring clustered with the remaining pool of oceanic stocks (Fig. 4). The sensitivity test of NSSH (2007 vs. 2014) did not alter this impression (Fig. 4). The first principle component explained $69.1 \%$, and the second trace, $23.5 \%$. A significant group effect was also observed (MANOVA-the Wilks lambda test; $p<0.001)$. 
Reproductive trade-offs by stock and region

\section{Analysis of selected reproductive traits}

Trade-offs between prespawning oocyte diameter (OD; "egg size") and length-specific fecundity $\left(\mathrm{RF}_{\mathrm{P}, \mathrm{TL}}{ }^{3}\right)$ clearly existed at the stock level (Fig. 5). Furthermore, prespawning OD and $\mathrm{RF}_{\mathrm{P}, \mathrm{TL}}{ }^{3}$ differed significantly among stocks (Kruskal-Wallis test; $p<0.001$ for both variables). Spring spawners predominately had $\mathrm{RF}_{\mathrm{P}, \mathrm{TL}}{ }^{3}<200 \mathrm{~cm}^{-3}$ and $\mathrm{OD}>1100$ $\mu \mathrm{m}$, i.e., were located in Quadrant 2 (Q2), whereas summer and autumn spawners had $\mathrm{RF}_{\mathrm{P}, \mathrm{TL}}{ }^{3-}$ $>200 \mathrm{~cm}^{-3}$ and $\mathrm{OD}<1100 \mu \mathrm{m}$, i.e., were located in Q4 (Fig. 5). Deviations from this pattern included NSAH (in Q2 instead of Q4) and both BSH and sGSLH (in Q4 instead of Q2). CAH and WSH were outside of this pattern, in Q1 and Q3, respectively (Fig. 5). For WSH, this may be due to high uncertainty because of few observations (Table 1). Higher withinstock variability $( \pm 95 \% \mathrm{CI}$ ) was generally observed for OD than $\mathrm{RF}_{\mathrm{P}, \mathrm{TL}}{ }^{3}$, especially for spring spawners (Fig. 5). The existence of interannual variability between $\mathrm{OD}$ and $\mathrm{RF}_{\mathrm{P}, \mathrm{TL}}{ }^{3}$ was exemplified for $\mathrm{NSSH}$, but these three sets all fell within the same quadrant, Q2 (Fig. 5). Finally, trade-offs by season were tested at the individual level (OD vs. $\mathrm{W}$ and $\mathrm{RF}_{\mathrm{P}, \mathrm{TL}}{ }^{3}$ vs. W), often with a large spread in data points within a given stock, including crossings of the above-mentioned threshold values (Figs. S3-S4), even in cases when the overall trade-off was within the expected quadrant (e.g., ISSH; Fig. 5).

\section{Reproductive discriminant analysis}

The selected set of reproductive variables, OD and $\mathrm{RF}_{\mathrm{P}, \mathrm{TL}}{ }^{3}$, resulted in a U-shaped scatterplot (Fig. 6). Overall, Northeast Pacific and local Norwegian herring stocks, jointly labelled as "local" (Table 1), formed one cluster, whereas the oceanic stocks in the Northwest and Northeast Atlantic formed another. However, NSSH and NSAH, both oceanic stocks, fell into the former category, whereas $\mathrm{CAH}$, a local stock, appeared in-between (Fig. 6). BSH was isolated from all the other herring stocks. For NSSH, all three plotted points fell within the same area of the graph (Fig. 6). The first trace explained $87.5 \%$ of the variation, and the second trace, $12.5 \%$, a significant group effect was recorded (MANOVA-the Wilks lambda test; $p<0.001)$.

Biometric-reproductive discriminant analysis

This combined analysis (Fig. S5) largely supported the above two separate analyses of a similar kind: Pacific and local Norwegian herring clustered, except their larger body-size members, $\mathrm{KBH}, \mathrm{LPH}, \mathrm{CSH}$, and LVH (Fig. 2), which joined with NSAH and NSSH (2007). GMH, sGSLH, ISSH, and NASH formed a third cluster, whereas NSSH (2014) appeared as an

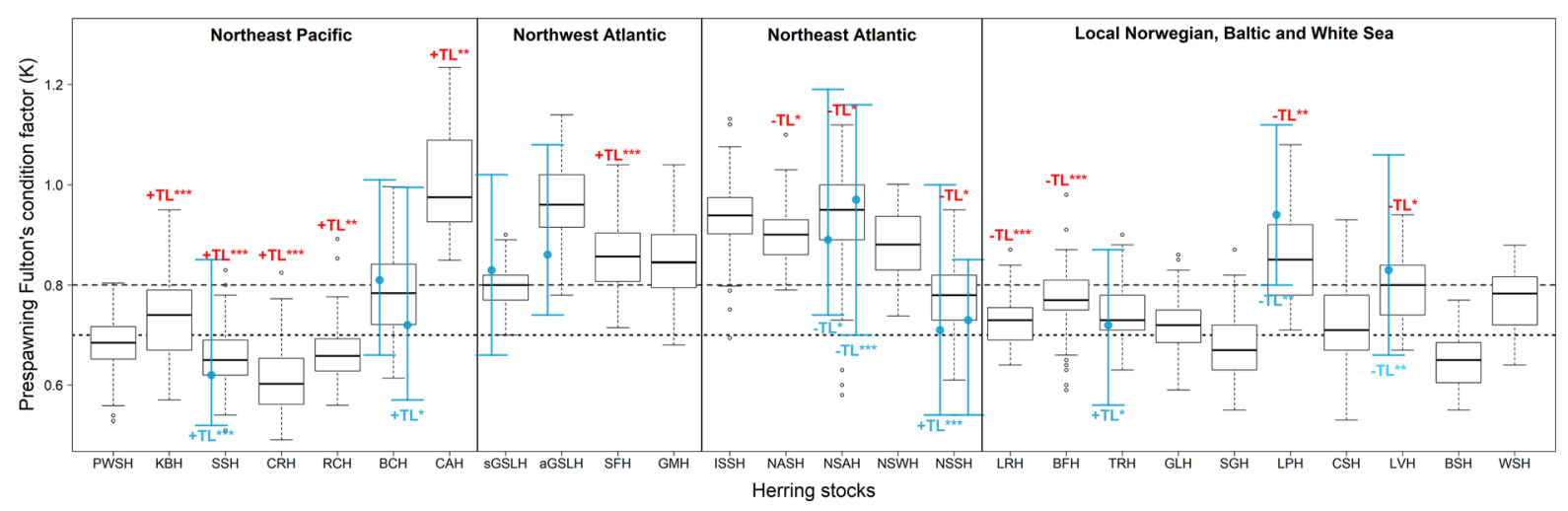

Fig. 3 Fulton's condition factor K for prespawning females across the examined herring stocks (Table 1), sorted by geographic region. For each box plot (main study), the thick line is the median value, top and bottom lines indicate the 75th and 25th percentiles, respectively, and whiskers indicate \pm 2 $\mathrm{SD}$. Seasonal variation is indicated for nine stocks (two additional years for $\mathrm{BCH}$, NSAH, and $\mathrm{NSSH}$ instead of one), with the filled circle indicating the median value (with $\pm 2 \mathrm{SD}$ whiskers). TL dependency, positive $(+)$ or negative $(-)$, is indicated as $* p<0.05, * * p<0.01$, and $* * * p<0.001 . \mathrm{K}=0.8$ is defined as a general reference line, whereas $\mathrm{K}=0.7$ represents the threshold between poor and good body condition of NSSH; $\mathrm{K}<0.7$ is associated with intensified atresia (Óskarsson et al. 2002) 


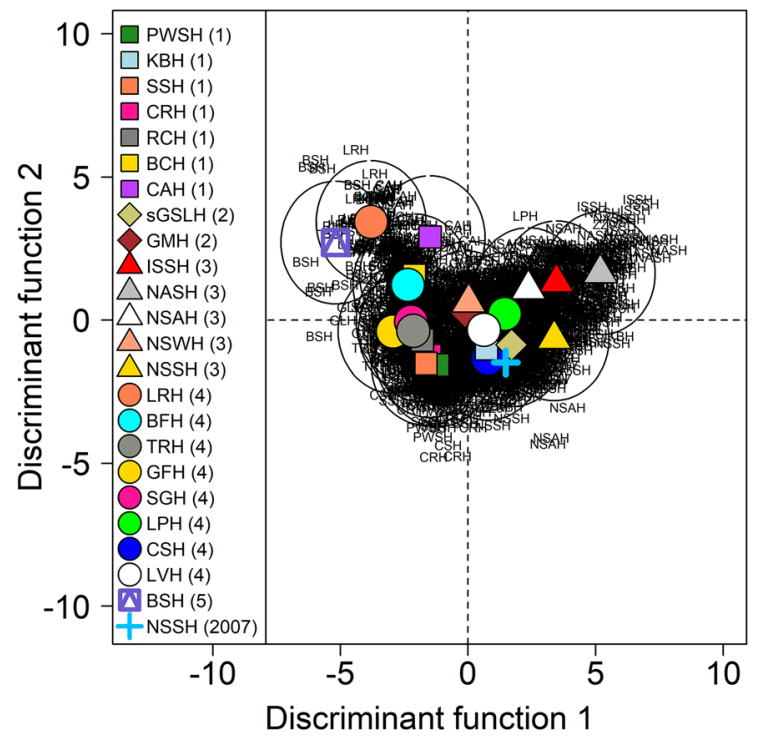

Fig. 4 Discriminant analysis scatterplot combining biometric (total length and whole body weight) and age data for herring stocks (Table 1), grouped by region: $1=$ Northeast Pacific; $2=$ Northwest Atlantic; $3=$ Northeast Atlantic; $4=$ Local Norwegian; and $5=$ Baltic Sea. The ellipsoid indicates the $90 \%$ tolerance interval, and the symbols represent the average value per stock. Missing age information for SFH and aGSLH (both in Region 2), and WSH (Region 6) precluded inclusion of these stocks. For NSSH, the output for 2014 (default) is compared to the output for 2007. Within each region, stocks are sorted by general herring stock location, from north (top) to south (except for the supplementary year for NSSH)

isolated spot in the plot, as well as BSH (Fig. S5). The first trace explained $49.7 \%$, and the second trace, $28.3 \%$, a significant group effect was recorded (MANOVA - the Wilks lambda test; $p<0.001$ ).

Oocyte and egg characteristics

OoW (oocyte wet weight) and OD were closely related, with NSAH possibly slightly off compared to the other stocks (Fig. S6a). Although EDW and OD also showed a strong positive relationship, at least for OD $>1100 \mu \mathrm{m}$, SFH with its the smaller ODs (700-1100 $\mu \mathrm{m})$ apparently followed a different trajectory for EDW (Fig. S7). Furthermore, EDW of NSAH hardly increased with OD. Due to many instances of little spread along the $\mathrm{x}$ axis regression analyses were not performed (Fig. S7). Water content estimates steadily increased with OD for SFH, whereas these were established at a higher plateau for the other stocks (Fig. S6b). All these presented

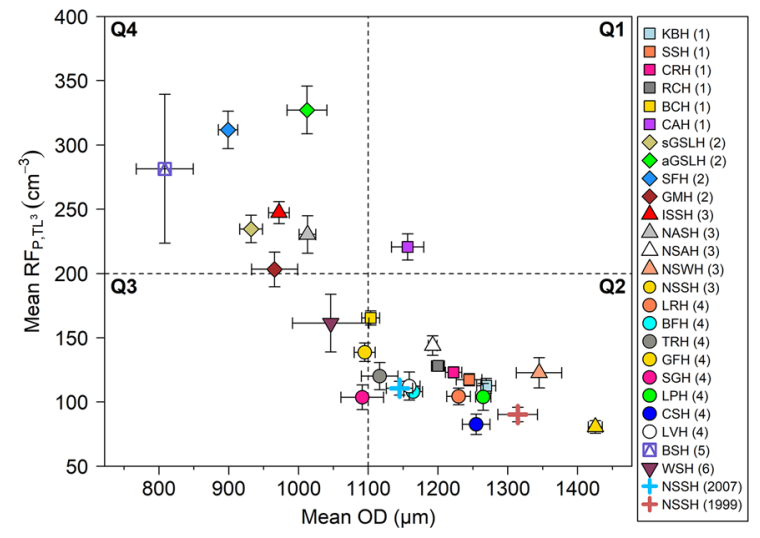

Fig. 5 Trade-off between mean oocyte diameter (OD) $( \pm 95 \%$ $\mathrm{CI})$ and relative length-based fecundity $\left(\mathrm{RF}_{\mathrm{P}, \mathrm{TL}}{ }^{3}\right)( \pm 95 \% \mathrm{CI})$ in prespawning individuals from different herring stocks (Table 1) located in the following geographic regions: $1=$ Northeast Pacific; 2 = Northwest Atlantic; $3=$ Northeast Atlantic; $4=$ Local Norwegian; $5=$ Baltic Sea; and $6=$ White Sea. Lines at $1100 \mu \mathrm{m}$ and $200 \mathrm{~g}^{-1}$ were used to divide the plot area into four quadrants (Q1-4), with most spring spawners occurring in Q2 and summer/autumn spawners in Q4. No reproductive data were available for PWSH (Region 1). For $\mathrm{NSSH}$, the default analysis (2014) was extended to include two additional years, 1999 and 2007. Within each region, stocks are sorted by main place attachment, from north (top) to south (except for the supplementary years for NSSH)

water content figures were, however, inflated by the inclusion of ovarian stroma. When the ovarian stroma were excluded the estimates fell from an average of 81.6 (STEP 1) to 70\% (STEP 2, published observations) in the case of NSSH, or, as determined by iteration, to be $\approx 15 \%$ of OoW, i.e., IF $=0.15$ (see Material and methods), in this stock at this prespawning stage.

\section{Reproductive investment}

In terms of absolute values, oceanic herring invested generally more in reproduction than local herring, regardless of spawning season (Fig. 7a). Following standardization by somatic body weight, this difference decreased but was still significant (KruskalWallis test, $p<0.001$ ) (Fig. 7b).

Relationship between fecundity, ovary size and body growth

Overall, both $\mathrm{F}_{\mathrm{P}}$ and $\mathrm{OW}$ increased in synchrony with body growth, but the similarity in this across-stock 


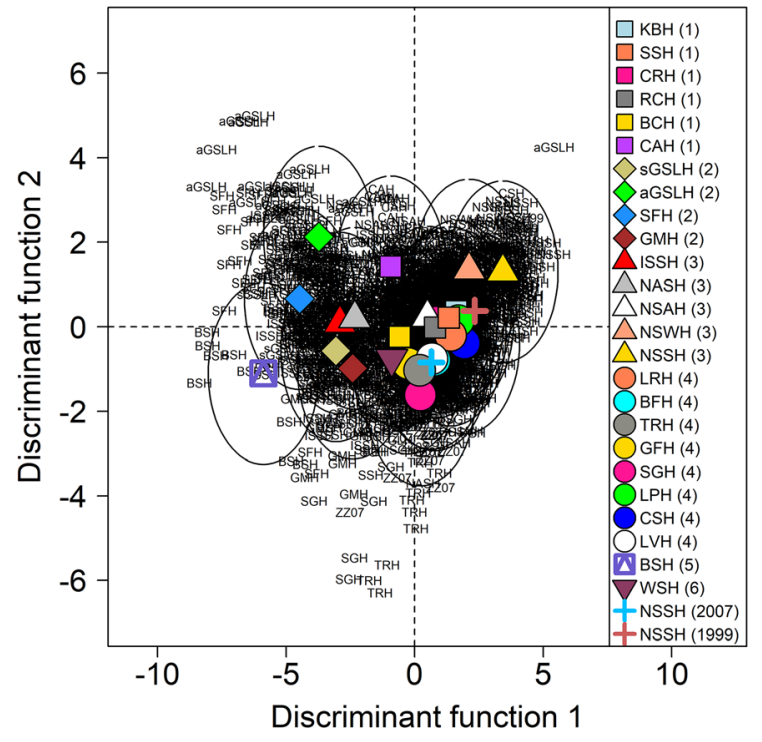

Fig. 6 Discriminant analysis scatterplot combining information on mean oocyte diameter (OD) and length-based relative fecundity $\left(\mathrm{RF}_{\mathrm{P}, \mathrm{TL}}{ }^{3}\right)$ of the studied herring stocks (Table 1) grouped by region: $1=$ Northeast Pacific; $2=$ Northwest Atlantic; 3 = Northeast Atlantic; 4 = Local Norwegian; $5=$ Baltic Sea; and $6=$ White Sea. The ellipsoid indicates a $90 \%$ tolerance interval, and symbols represent the average value per stock. PWSH (Region 1) is not represented. For NSSH, the output for 2014 (default) is compared to the outputs for 1999 and 2007. Within each region, stocks are sorted by main place attachment, from north (top) to south (except for the supplementary years for NSSH)

trend was more evident for OW (Fig. 8). As the herring grew from age 4 to 6 years, the relationship turned steeper, again more clearly seen with OW as the response variable. Focusing on the latter, TRH exemplified a "catching up" trend, while the observation for the $\mathrm{CAH}$ set became progressively more extreme.

Relationship between body condition and in situ temperature

Mean prespawning $\mathrm{K}$ and annual mean temperature showed a weak positive relationship (ANOVA, $r=0.298 ; p<0.001$ ), where CAH was isolated, with the highest condition at the highest annual mean temperature, followed by most of Northwest and Northeast Atlantic herring stocks (except NSSH) but also LPH (cf. Figure 3). K was typically around 0.9 in these cases referring to a temperature range of 7.5 to $12.5^{\circ} \mathrm{C}$ (Fig. 9a). The remaining herring stocks showed mean $\mathrm{K} \leq 0.8$ for $4-10.5{ }^{\circ} \mathrm{C}$. Mean $\mathrm{K}_{\mathrm{n}}$ and annual mean temperature showed a flatter relationship but still significant (ANOVA, $r=0.274 ; p<0.001$ ), except for $\mathrm{CAH}$ that showed an extremely high value compared to the other herring stocks (Fig. 9b). The two GSLH stocks were not included in these relationships for reasons outlined in the Material and methods.

\section{Discussion}

This analysis of 26 herring stocks had three main functions: (i) the demonstration of possibly several unique stock-specific traits, (ii) illustrate the potential utility of the present work as a platform for further studies, and (iii) as a useful reference for monitoring effects of on-going climate change (IPCC 2018) on herring trait expressions. Due to the rich variety of reproductively isolated stocks for both Clupea pallasii and C. harengus (Hay et al. 2001; Geffen 2009), this review and meta-analysis required extensive co-operation across laboratories to adequately contrast reproductive performance and corresponding body metrics of herring located in different and distant waters. Thus, this work was made possible by a compilation of available national data sets and by acquiring new information on several herring stocks. Our work is special in the herring literature because of the comprehensive list of variables considered along the axes of both reproduction and biometrics, replacing historic laboratory techniques within the field of reproductive analyses with modern techniques, and, not at least, examination of the material for individual variability rather than addressing only pooled data. To the best of our knowledge, this study is the first thorough comparison of Pacific and Atlantic herring reproductive traits. Most of the earlier, relevant information seems to be restricted to either Pacific (e.g. Tanasichuk and Ware 1987; Hay et al. 2008) or Atlantic herring stocks (Parrish and Saville 1965; Blaxter 1985). The life-history of the 26 herring stocks refer to different areas and migratory styles, i.e., from a relatively stationary (local) to highly migratory (oceanic) behaviour. We also considered herring stocks distributed over extensive latitudes (from approximately 40 to $70^{\circ} \mathrm{N}$ ), with different day lengths (Sundby et al. 2016). Furthermore, both unproductive habitats (e.g., the high-latitude sea loch of LRH) (Hognestad 1994; Mikkelsen et al. 2018) and highly productive habitats (e.g., the temperate eastern 

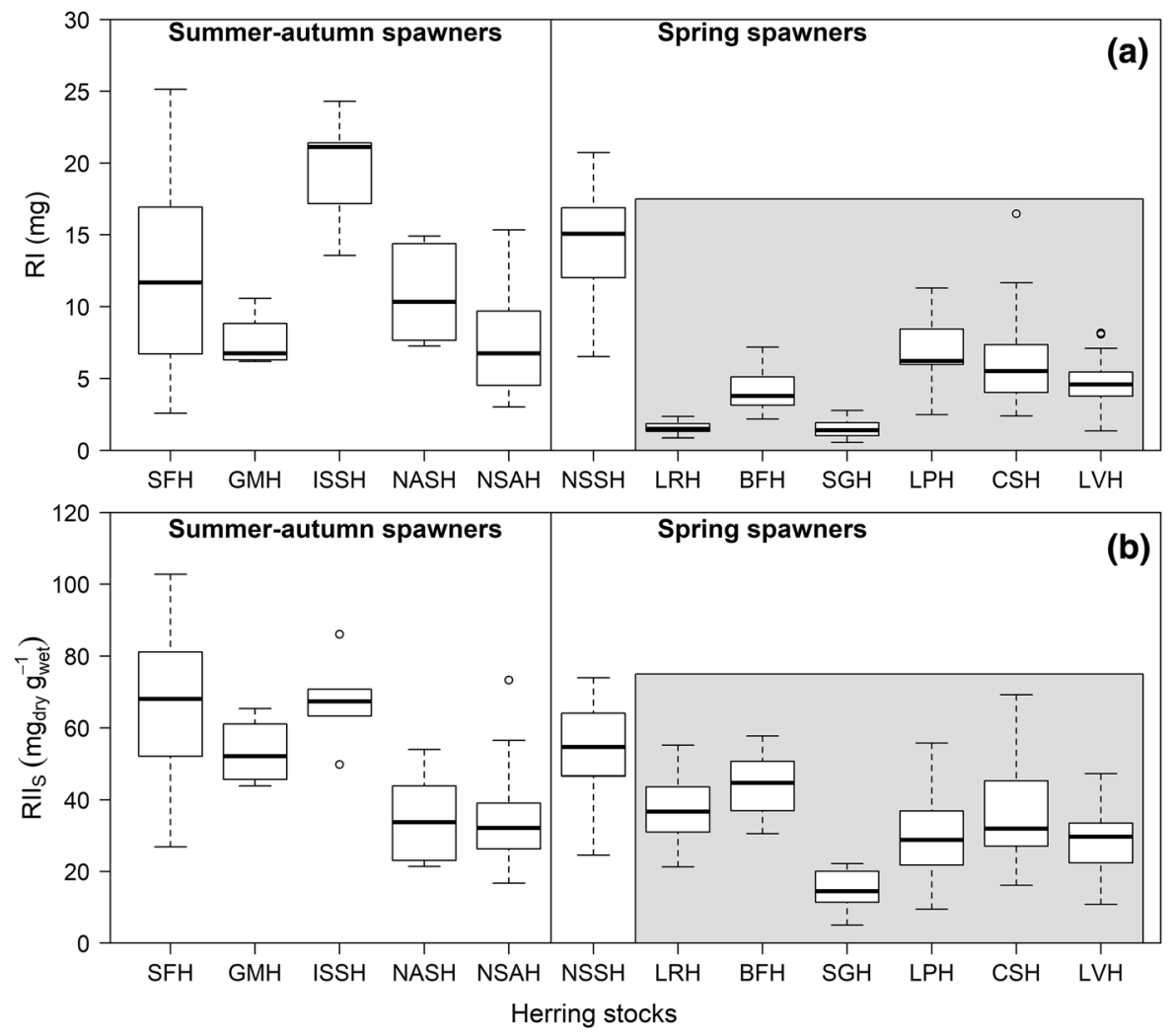

Fig. 7 Reproductive investment (RI) (upper panel) and reproductive investment standardized by somatic weight $\left(\mathrm{RII}_{\mathrm{S}}\right)$ (lower panel) as recorded for different herring stocks (Table 1), sorted by spawning season. Stocks are further distinguished based on their distribution: oceanic versus local (grey box). For

boundary upwelling zone (Field et al. 1998) inhabited by $\mathrm{CAH}$ ) were included. So, our results should provide a representative overview of the scope of reproductive trade-offs for these ecologically important clupeids, including several stocks of high economic value (Hay et al. 2001). Though it is beyond the scope of this work to elaborate on phylogenetics, both LRH and BFH were identified as " $C$. pallasii peripheral populations" in Libungan et al. (2016). In Mikkelsen et al. (2018), $\mathrm{LRH}$ and $\mathrm{BFH}$ were identified as C. pallasii rather than $C$. harengus. However, because the other local Norwegian herring stocks considered should all be considered $C$. harengus (Martinez Barrio et al. 2016), we opted for geographic region as one of the separation criteria instead of genetics.

A limitation of our work is the general lack of time series data, especially regarding complete sets of reproductive traits of current interests, although we applied sensitivity analyses attempting to address this each box plot, the thick line is the median value, top and bottom lines indicate the 75th and 25th percentiles, respectively, and whiskers indicate \pm 2 SD. Stocks in the Northeast Pacific are not represented due to lack of egg dry weight data

concern. However, we understand that significant lag effects might be important requiring additional complex data sets, but they were inaccessible across most of stocks in our pilot studies. For example, the fecundity of NSSH is not only a function of prey availability and thereby body condition during the current season, but also during previous seasons (i.e., at oogonial proliferation) (dos Santos Schmidt et al. 2017). Moreover, environmental conditions among different regions may not fluctuate synchronously, e.g., a positive North Atlantic Oscillation Index (NAOI) creates a relatively warmer situation in the northeast Atlantic but a relatively cooler situation in the northwest Atlantic (Bjerknes 1962; Sundby and Drinkwater 2007). A negative NAOI will reverse this situation. Over the last 50 years, Northeast Atlantic herring stocks have been exposed to warmer temperatures caused by positive phase of another mode of natural climate variability, the larger-scale Atlantic 


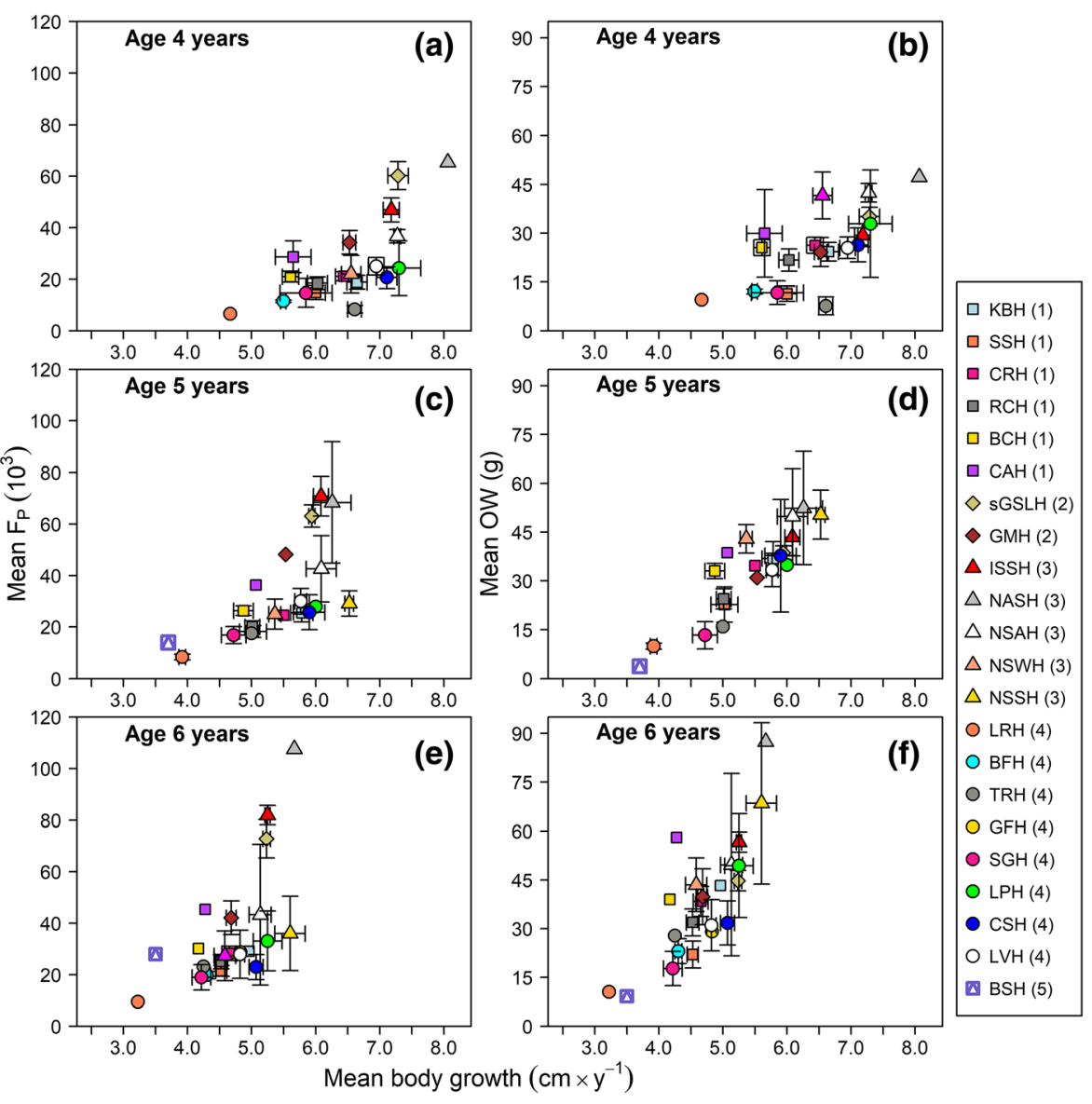

Fig. 8 Relationship between mean body growth $( \pm 95 \% \mathrm{CI})$ and mean potential fecundity $( \pm 95 \% \mathrm{CI})(\mathrm{a}, \mathrm{c}$, and e) and mean ovary weight $( \pm 95 \% \mathrm{CI})(\mathrm{b}, \mathrm{d}$, and $\mathrm{f})$, split by age class. The herring stocks are organized by region: $1=$ Northeast Pacific;

Multidecadal Oscillation (AMO; Drinkwater et al. 2014; Hoegh-Guldberg et al. 2014) that has influenced the entire North Atlantic synchronously. Temperature also varies in these regions based on different water currents and/or local habitat condition where each herring stock lives (see Material and Methods). Therefore, herring collected on each side of the Atlantic should not be uncritically compared regarding seasonal attributes, such as body condition (Sande et al. 2019). Along the same lines, Pacific herring can be affected by the El Niño Southern Oscillation (Bailey et al. 1995; Lehodey 2001), and the largerscale and interannual to multidecadal time scale, Pacific Decadal Oscillation (PDO) (Mantua and Hare 2002) with particular impact in the North Pacific north of $20^{\circ} \mathrm{N}$ with opposite phases in the Northwest and Northeast Pacific. PDO has been ascribed to influence
$2=$ Northwest Atlantic; $3=$ Northeast Atlantic; $4=$ Local Norwegian; $5=$ Baltic Sea; and $6=$ White Sea. PWSH, aGSLH, SFH, and WSH were excluded due to lack of fecundity or age data

Northeast Pacific herring stocks, such as stock size of BCH (Landis et al. 2003). Additionally, within the herring habitats of the North Pacific and North Atlantic there are recent differences in temperature trends. In the California Current (habitat of CAH) and in the Gulf of Saint Lawrence (habitat of sGSLH and aGSLH) the long-term temperature has remained nearly constant, while in the northern parts of the Northeast Pacific (habitat of BCH, RCH, CRH, SSH, $\mathrm{KBH}$, and $\mathrm{PWSH}$ ) the temperature has increased, as noticed in the above-mentioned climate literature. All of the Northeast Atlantic herring stocks have experienced a substantial temperature increase since 1970s. This is caused by amplification of the combined effects of the positive phase of AMO and the global anthropogenic climate change (Hoegh-Guldberg et al. 2014). These changes are clearly reflected in the three 


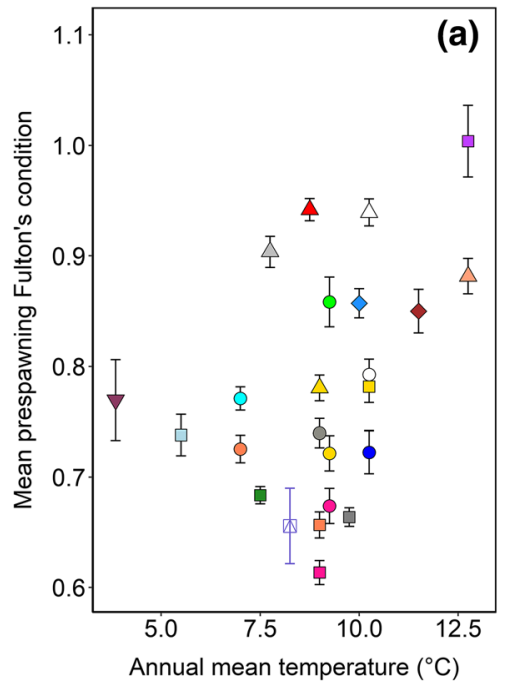

Fig. 9 Relationship between body condition factor, either Fulton's condition (a) or relative condition (b), and annual mean temperature from 1955 to 2017. aGSLH and sGSLH are not included due to strong vertical thermal stratification (Table S1) along with complex migration routes (see Material and

temperature time intervals presented in Table S1. The largest sea surface temperature (SST) increase has been experienced by BSH and WSH. This is linked to the larger thermal stratification in these two regions. Additionally, sGSLH and aGSLH are also living in highly stratified waters; the two Gulf of Saint Lawrence stocks are subjected to special thermal conditions caused by inflow of the so-called Cool Intermediate Layer (CIL) from the Labrador Current with its core vertically extending between 30 and $100 \mathrm{~m}$ depth (Gilbert and Pettigrew 1997). Here, temperature at $30 \mathrm{~m}$ depth was about $\leq 3{ }^{\circ} \mathrm{C}$ during the sampling of the stocks in the $1970 \mathrm{~s}$ and at $100 \mathrm{~m}$ depth only $2{ }^{\circ} \mathrm{C}$ as an annual average. The CIL is more dominant in the northernmost part of the Gulf of Saint Lawrence. Hence, the spring-spawning stock (sGSLH) is most influenced of the two. It is uncertain if the herring would avoid such depths due to the low temperature. Hopefully, our work will encourage lengthy sampling programs in both oceans to assess differences in environmental impacts on herring reproductive ecology in a more comprehensive manner. Body growth was currently used as a metric to reflect environmental influences (see Sande et al. 2019 and references therein), as addressed below.

Distinct differences in biometric and reproductive features were identified when compared across all

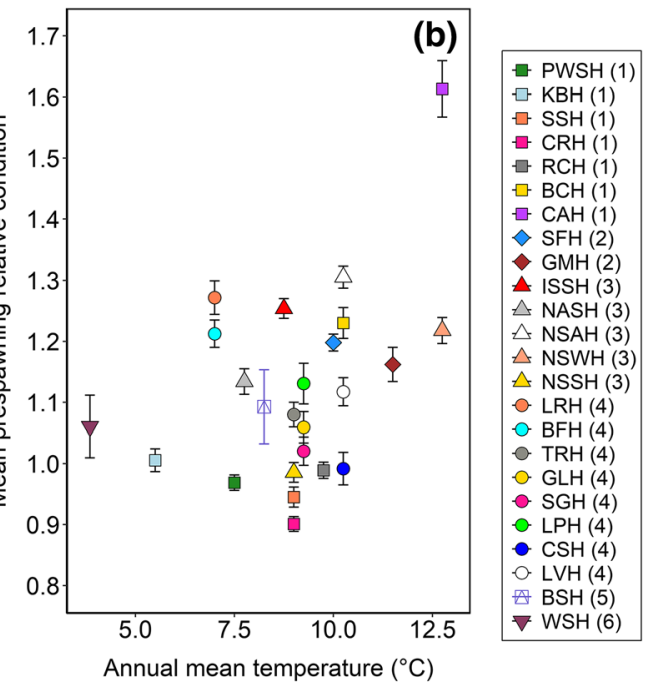

methods). The herring stocks are organized by region: $1=$ Northeast Pacific; 2 = Northwest Atlantic; 3 = Northeast Atlantic; 4 = Local Norwegian; $5=$ Baltic Sea; and $6=$ White Sea

herring stocks. Northeast Pacific and local Norwegian herring stocks often exhibited similarities, whereas oceanic Atlantic herring stocks tended to form another separate subset. Thus, the noted patterns often referred to geographic location (or region) rather than species (C. harengus vs. C. pallasii), emphasizing the importance of local adaptations. Northeast Pacific herring showed a positive effect of latitude on body size, which was well-documented previously (Tanasichuk et al. 1993; Hay et al. 2008; Ito et al. 2015). This northward trend seems to also occur among Northeast Atlantic herring stocks, but it was inversed for local Norwegian herring. Hay et al. (2008) speculated that this latitudinal gradient in body size may be related to environmental conditions in each living area. Generally, body growth (length-at-age) and condition (weight-at-length, $\mathrm{K}$ or $\mathrm{K}_{\mathrm{n}}$ ) varied between oceanic and local herring stocks; oceanic herring typically had faster growth rates and stouter body shape. Parrish and Saville (1965) extensively compared the morphological features of oceanic and "shelf" stocks, with the latter represented by different North Sea herring stocks. They summarized oceanic herring as having a long-life span, large body size, and late maturation, whereas coastal/local herring were completely opposite. The generally larger body size of oceanic herring is probably attributable to their longer migration 
routes (Dragesund et al. 1997). For example, in recent years, NSSH have migrated from feeding grounds in the Norwegian Sea to overwintering areas outside northern Norway before moving on again to the main spawning grounds further south along the coast off western Norway, an annual migration distance $>2700 \mathrm{~km}$ (Huse et al. 2010). In contrast, local Norwegian stocks are mainly restricted to the fjords (Lie et al. 1978; Hognestad, 1994). LRH migrate in an irregular fashion, without forming any school, inside the small $12 \mathrm{~km}$ long and $1 \mathrm{~km}$ wide lake (Hognestad 1994). Pacific herring also exhibit variability in migration distance. The prime example of long migration in these waters is Togiak herring in the Alaskan Bering Sea, which migrate into inshore areas (Bristol Bay) during the spawning season but stay offshore (Unimak Pass and between Pribilof Islands and St. Matthew Island) during the overwintering and feeding period, migrating $\sim 2100 \mathrm{~km}$ over this time period (Tojo et al. 2007). At the other end of the scale in these waters are $\mathrm{BCH}$, a herring of smaller body size, which spawn in the Strait of Georgia and feed in shelf regions off the west coast of Vancouver Island, covering a total distance of $400 \mathrm{~km}$ (Hay et al. 2001). Not surprisingly, herring migration distance is related to body size; larger fish will spend less metabolic energy during migration than smaller fish (Slotte 1999; Nøttestad et al. 1999). Thus, larger herring can utilize distant productive areas, which should further support faster growth and greater reproductive investment. There are exceptions to these generalizations; the local Norwegian herring stocks LPH, CSH, and LVH grew roughly in the same way as the oceanic stocks. Their large size has been attributed to cooccurrence with NSSH (Silva et al. 2013) and other coastal herring stocks (e.g., Skagerrak, and Kattegat herring) (Johannessen et al. 2009, 2014; Eggers et al. 2014; Berg et al. 2017). More specifically, LPH have interacted with NSSH over prolonged periods, but mainly during the NSSH stock collapse in the late 1960s when its distribution was highly restricted over a couple of decades to near the Norwegian coast (Johannessen et al. 2014). Here we found that autumn spawners tend to have higher body condition, but lower body growth compared to spring spawners, agreeing with findings in Berg et al. (2020) studying a herring fjord population complex near Bergen, Norway. The higher prespawning body condition of autumn spawners may be explained by that the feeding season to a larger extent overlap with the main part of gametogenesis reducing the depletion of surplus energy compared to spring spawners displaying fast gonad growth during late autumn and early winter (Kurita et al. 2003; dos Santos Schmidt et al. 2017) (see below). Recently, it has been demonstrated that the combination of three approaches, such as maturity stage, otoliths microstructure and, genetics analysis based on single nucleotide polymorphisms can be a better tool to distinguish between spring and autumn spawners (Berg et al. 2020). Although, most of the herring stocks studied here were spring spawners ( $\mathrm{n}=19$ ) and samples were collected prior to spawning which unequivocally allows for the correct assessment of spawning seasons, the applicability of these three approaches combined could be an effective tool on sympatric stocks, such as Gulf of Saint Lawrence herring.

Apart from intrinsic factors, extrinsic factors may also influence the body condition of herring. Although the relationship with ambient temperature across the entire thermal range appears highly scattered, there is, statistically speaking, a positive correlation. One may speculate what is the mechanistic link between temperature and the consulted measures of body condition ( $\mathrm{K}$ and $\mathrm{K}_{\mathrm{n}}$ ). Most probably, temperature is a proxy for other extrinsic factors such as integrated primary production, which might have some latitudinal variation and which in turn is affected by ocean temperature. Moreover, spatial changes in primary production will cascade into the abundance of zooplankton food abundance.

Earlier studies indicate that a trade-off between fecundity and egg size is to be expected among herring stocks, at least for Atlantic herring (Blaxter and Holliday 1963; Hempel and Blaxter 1967; Blaxter 1985). The most evident explanation is the timing of egg production, spring versus autumn spawners, in relation to peaks in prey abundance for the startfeeding larvae, which has been studied extensively (Cushing 1967; Hempel and Blaxter 1967; van Damme et al. 2009; dos Santos Schmidt et al. 2017). We systematized the available reproductive information by splitting the $\mathrm{RF}_{\mathrm{P}, \mathrm{TL}}{ }^{3}$ - $\mathrm{OD}$ diagram into four quadrants using $\mathrm{RF}_{\mathrm{P}, \mathrm{TL}}{ }^{3}=200$ oocytes $\mathrm{cm}^{-3}$ and $\mathrm{OD}=1100 \mu \mathrm{m}$ as thresholds. In general, summer and autumn spawners produce many smaller eggs (Q4), whereas spring and winter spawners produce relatively fewer, but large eggs (Q2) (Parrish and Saville 
1965; Hempel and Blaxter 1967; dos Santos Schmidt et al. 2017). We found that Pacific herring (spring spawners) fit into this scheme, though not the southernmost stock located in an upwelling area, the $\mathrm{CAH}$, which is apparently energetically able to produce many large eggs. Local Norwegian herring (spring spawners) also fit, though not WSH, perhaps due to the extreme cold fjord habitat (Pesciaroli et al. 2012). Fundamentally speaking, these differences in reproductive allocation patterns (i.e., egg size vs. fecundity) are regulated by the length of the reproductive cycle: winter and spring spawners with a longer period of vitellogenesis (extended yolk uptake), whereas autumn spawners have a shorter period (Parrish and Saville 1965; van Damme et al. 2009; dos Santos Schmidt et al. 2017) (see also above). However, a lengthened reproductive cycle comes at the cost of increased energy expenditure and higher prevalence of atresia (Kurita et al. 2003; van Damme et al. 2009). Óskarsson et al. (2002) found that EDW and OD are tightly coupled in NSSH. However, this link varies among stocks; for example, for NSAH we found indications that oocytes may grow without any further increase in EDW (arrested yolk uptake). The underlying reason is evasive, as NSAH fell in Q2 rather than $\mathrm{Q} 4$ as expected in the $\mathrm{RF}_{\mathrm{P}, \mathrm{TL}}{ }^{3}$ - OD diagram. Another pattern in the associated EDW-OD plot was that SFH stayed in the so-called atretic window $(800<$ OD $<$ $1000 \mu \mathrm{m}$ ) towards spawning, i.e., past this window, energetic costs markedly increase due to the exponential increase in OD, and therefore EDW (Kurita et al. 2003). Intensified atresia is thought to provide energy (or vitellogenin directly) to neighbouring developing oocytes (Kurita et al. 2003). The fecundity of SFH was extremely high, i.e., at the same level as the much larger aGSLH adults, which are also found in the same region, indicating that atresia was not a major issue in SFH females. Apparently, both SFH and NSAH have opted for different reproductive tactics to lessen the extra cost associated with accelerated vitellogenic sequestration. Complementing estimations of the overall reproductive investment standardized for somatic body size $\left(\mathrm{RII}_{\mathrm{S}}\right)$ clarified that these figures were much higher in SFH than NSAH. Unfortunately, EDW data were not available for Pacific herring, but we found that local herring clearly invest less in reproduction than their oceanic counterparts, a finding that is in line with the above elaborations on body size-related issues in less and more productive habitats.

The use of ovary weight (OW) as a proxy for reproductive investment turned out successful when related to body growth, the latter taken as a spatiotemporal integrator of ambient environmental conditions (Sande et al. 2019). First, OW was reported for all stocks except one. Likewise, body growth at age 4, 5 , and 6 years could be provided for most stocks. An unexpectedly tight relationship between OW and body growth occurred across stocks, underlining similar fundamental energy allocation patterns for both $C$. harengus and C. pallasii, and some of the variation is likely explained by spawning season: spring versus summer-autumn spawners. These plots also clarified that older specimens progressively invest relatively more in reproduction. Logically, the relationship between $\mathrm{F}_{\mathrm{P}}$ and body growth was less clear due to the outlined phenomenon of well-developed trade-offs between $F_{P}$ and $\mathrm{OD}$ (EDW) implying that $\mathrm{F}_{\mathrm{P}}$ only partly explains OW dynamics. Further to this, the related exercise of estimating oocyte wet weight (OoW) resulted in an exceedingly strong physical relationship between OoW and OD, not only telling that $F_{P}$ and $\mathrm{OW}$ were recorded correctly across laboratories, but also that the relative amount of ovarian stroma appears consistent. The indicated level of $15 \%$ stroma for NSSH is, however, higher than expected; Hay and Brett (1988) state this to be $<5 \%$. This topic should be followed up by measurements of spent ovary weights (Hay and Brett 1988) but also stereological examinations (Serrat et al. 2019).

Our approach was extensive, studying 26 herring stocks in different waters in the Northern hemisphere. Newer data were compiled and analysed, split by stock. Prespawning Pacific and Atlantic herring, as well as local Norwegian herring, were compared methodically in terms of reproductive traits, with local Norwegian herring largely exhibiting a similar pattern as Pacific herring, whereas Atlantic herring deviated. Plots on EDW as a function of OD revealed unexpected patterns (e.g., less or arrested accumulation of egg mass, likely to save energy). Overall, the analysis demonstrated a significant degree of plasticity in reproductive traits across stocks in association with great variability both in body condition and growth. This kind of plasticity is an important mechanism for herring as a species to respond to changing environmental conditions, including seasonal pulses of energy 
that may or may not coincide with oocyte development. Nevertheless, body growth and reproductive investment seem to be closely coupled for all herring stocks examined speaking for general energy allocation principles. However higher efficiency of direct energy allocation to ovary (offsetting metabolic costs of energy transfer and storage/maintenance) may allow summer-autumn spawners to allocate more energy to reproduction than spring spawners. Our study does not provide any evidence that the present extent of climate change (IPCC 2018) has affected herring reproductive trade-offs. Therefore, we would recommend the continuation or establishment of dedicated reproductive ecology time series, in parallel with data collection as part of stock assessment because the reproductive potential (status) is an integral component of the following stock advice provided.

Acknowledgements Sherri C. Dressel (Alaska Department of Fish and Game, Juneau, Alaska, USA), Scott Pegau (Oil Spill Recovery Institute, Cordova, Alaska, USA), Doug P. Swain (Gulf Fisheries Centre, Fisheries and Oceans Canada, Moncton, Canada), and Rod G. Bradford (Population Ecology Division, Fisheries and Oceans Canada, Dartmouth, Canada) are warmly thanked for providing data sets on Alaska herring stocks and Gulf of Saint Lawrence herring. The authors are also thankful to those involved in sampling additional material on herring: Torstein Pedersen and Nina Mikkelsen (The Arctic University of Norway, Troms $\varnothing$ ), Florian Berg, Jostein Røttingen, and Ørjan Sørensen (Institute of Marine Research [IMR], Bergen), and emeritus Knut Hansen (IMR, Flødevigen). A special thank you goes to Jan de Lange and Bjørn Vidar Svendsen (IMR, Bergen) for all their indispensable efforts in the laboratory. Alain F. Zuur and Elena N. Ieno are thanked for providing statistical advice. The first author was supported by a PhD Grant (No. 240467, 2012-4) through the National Council of Scientific and Technological Development $(\mathrm{CNPq}-$ Brazil). The production of this manuscript was also made possible by the project Climate and Vital Rates of Marine Stocks (CLIMRATES, No. 15205) and Recruitment Dynamics of Commercially Important Fish Species in Changing NE Atlantic ecosystems (RECNOR, No. 14861), both funded by the Norwegian Fisheries Research Sales Tax System (FFA). Dmitry Lajus was supported by the Russian Science Foundation (Grant No. 19-14-00092).

Author contribution TCdSS, DEH, and OSK conceptualized the idea of the review. TCdSS, DEH, SS, GJO, AS, MJW, DL, AJ, SCD, CVD, and RHB performed the data collation. TCdSS and JAD analysed the data. TCdSS, OSK, SS, and DEH wrote the manuscript. All authors contributed to editing the review.

Funding Open access funding provided by Institute Of Marine Research.
Open Access This article is licensed under a Creative Commons Attribution 4.0 International License, which permits use, sharing, adaptation, distribution and reproduction in any medium or format, as long as you give appropriate credit to the original author(s) and the source, provide a link to the Creative Commons licence, and indicate if changes were made. The images or other third party material in this article are included in the article's Creative Commons licence, unless indicated otherwise in a credit line to the material. If material is not included in the article's Creative Commons licence and your intended use is not permitted by statutory regulation or exceeds the permitted use, you will need to obtain permission directly from the copyright holder. To view a copy of this licence, visit http://creativecommons.org/licenses/by/4.0/.

\section{References}

Bagenal TB (1978) Aspects of fish fecundity. In: Gerking SD (ed) Ecology of freshwater fish production. Halsted Press, Wiley, New York, pp 75-101

Bailey KM, Macklin SA, Reed RK et al (1995) ENSO events in the northern Gulf of Alaska, and effects on selected marine fisheries. CalCOFI Rep 36:78-96

Bancroft JD, Stevens A (1996) Theory and practice of histological techniques. Churchill Livingstone, New York

Berg F, Slotte A, Johannessen A, Kvamme C, Clausen LW, Nash RDM (2017) Comparative biology and population mixing among local, coastal and offshore Atlantic herring (Clupea harengus) in the North Sea, Skagerrak, Kattegat and western Baltic. PLoS ONE 12:e0187374

Berg F, Østgaard HD, Slotte A, Andersson L, Folkvord A (2020) A combination of genetic and phenotypic characterization of spring- and autumn-spawning herring suggests gene flow between populations. ICES J Mar Sci. https://doi.org/ 10.1093/icesjms/fsaa046

Bjerknes J (1962) Synoptic survey of the interaction between sea and atmosphere in the North Atlantic. Geofys Publ 24:116-145

Blaxter JHS (1985) The herring: a successful species? Can J Fish Aquat Sci 42:21-30

Blaxter JHS, Holliday FGT (1963) The behaviour and physiology of herring and other Clupeids. Adv Mar Biol 1:261-393

Bradford RG, Stephenson RS (1992) Egg weight, fecundity, and gonadal weight variability among Northwest Atlantic herring (Clupea harengus) populations. Can J Fish Aquat Sci 49:2045-2054

Brannian LK, Yuen HJ, McCracken BW (1995) An estimate of Kamishak Bay herring fecundity. Regional information report no. 2A95-07. Alaska Department of Fish and Game, Alaska, Anchorage

Bucholtz RH, Tomkiewicz J, Nyengaard JR, Andersen JB (2013) Oogenesis, fecundity and condition of Baltic herring (Clupea harengus L.): a stereological study. Fish Res 145:100-113 
Buzeta MI, Waiwood KG (1982) Fecundity of Atlantic cod (Gadus morhua) in the southwestern Gulf of St. Lawrence. Can Tech Rep Fish Aquat Sci 1110:1-6

Comeau LA, Campana SE, Chouinard GA (2002) Timing of Atlantic cod (Gadus morhua L.) seasonal migrations in the southern Gulf of St Lawrence: interannual variability and proximate control. ICES J Mar Sci 59:333-351

Cushing DH (1967) The grouping of herring populations. J Mar Biol Ass UK 47:193-208

dos Santos Schmidt TC, Slotte A, Kennedy J, Sundby S, Johannessen A, Óskarsson GJ, Kurita Y, Stenseth NC, Kjesbu OS (2017) Oogenesis and reproductive investment of Atlantic herring are functions of not only present but long-ago environmental influences as well. Proc Natl Acad Sci USA 114:2634-2639

Dragesund O, Hamre J, Ulltang Ø (1980) Biology and population dynamics of the Norwegian spring-spawning herring. Rapp P-v Réun Cons Int Explor Mer 177:43-71

Dragesund O, Johannessen A, Ulltang Ø (1997) Variation in migration and abundance of Norwegian spring spawning herring (Clupea harengus L.). Sarsia 82:97-105

Drinkwater KF, Miles M, Medhaug I, Otterå OH, Kristiansen T, Sundby S, Gao Y (2014) The Atlantic Multidecadal Oscillation: Its manifestations and impacts with special emphasis on the Atlantic region north of $60^{\circ} \mathrm{N}$. J Mar Syst 133:117-130

Eggers F, Slotte A, Libungan LA, Johannessen A, Kvamme C, Moland E, Olsen EM, Nash RDM (2014) Seasonal dynamics of Atlantic herring (Clupea harengus L) populations spawning in the vicinity of marginal habitats. PLoS ONE 9:e111985

Field CB, Behrenfeld MJ, Randerson JT, Falkowski P (1998) Primary production of the biosphere: integrating terrestrial and oceanic components. Science 281:237-240

Garcia HE, Boyer TP, Baranova OK et al (2019) World Ocean Atlas 2018: Product Documentation. Mishonov, A. Technical Editor. https://data.nodc.noaa.gov/woa/WOA18/ DOC/woa18documentation.pdf

Geffen A (2009) Advances in herring biology: from simple to complex, coping with plasticity and adaptability. ICES J Mar Sci 66:1688-1695

Gilbert D, Pettigrew B (1997) Interannual variability (1948-1994) of the CIL core temperature in the Gulf of St. Lawrence Can J Fish Aquat Sci 54(Suppl. 1):57-67

Hay DE (1985) Reproductive biology of Pacific herring (Clupea harengus pallasi). Can J Fish Aquat Sci 42:111-126

Hay DE (1986) Effects of delayed spawning on viability of eggs and larvae of Pacific herring. Trans Am Fish Soc 115:155-161

Hay DE, Brett R (1988) Maturation and fecundity of Pacific herring (Clupea harengus pallasi): an experimental study with comparisons to natural populations. Can J Fish Aquat Sci 45:399-406

Hay DE, Brett JR, Bilinski E, Smith DT, Donaldson EM, Hunter GA, Solmie AV (1988) Experimental impoundments of prespawning Pacific herring (Clupea harengus pallasi): effects of feeding and density on maturation, growth, and proximate analysis. Can J Fish Aquat Sci 45:388-398

Hay DE, Toresen R, Stephenson R et al (2001) Taking stock: an inventory and review of world herring stocks in 2000. In: Funk F, Blackburn J, Hay D, Paul AJ, Stephenson R,
Toresen R, Witherell D (eds) Herring: expectations for a new millennium. University of Alaska Sea Grant College Program, Fairbanks, pp 381-454

Hay DE, Rose KA, Schweigert J, Megrey BA (2008) Geographic variation ion North Pacific herring populations: Pan-Pacific comparisons and implications for climate change impacts. Prog Oceanogr 77:233-240

Hempel G, Blaxter JHS (1967) Egg weight in Atlantic herring (Clupea harengus L.). J Cons Int Explor Mer 31:170-195

Hislop JRG, Bell MA (1987) Observations in the size, dry weight and energy content of the eggs of some demersal fish species from British marine waters. J Fish Biol 31:1-20

Hoegh-Guldberg O, Cai R, Poloczanska ES, Brewer PG, Sundby S, Hilmi K, Fabry VJ, Jung S (2014) The ocean. In: Barros VR, Field CB, Dokken DJ et al (eds) Climate change 2014: impacts, adaptation, and vulnerability. Part $\mathrm{B}$ : regional aspects. Contribution of working group II to the fifth assessment report of the intergovernmental panel on climate change. Cambridge University Press, Cambridge, pp 1655-1731

Hognestad PT (1994) The Lake Rossfjord herring (Clupea harengus L.) and its environment. ICES J Mar Sci 51:281-292

Holst JC, Røttingen I, Melle W (2004) The herring. In: Skjoldal HR, Sætre R, Fernö A, Misund OA, Røttingen I (eds) The Norwegian Sea ecosystem. Tapir Academic Press, Trondheim, pp 203-226

Huse G, Fernö A, Holst JC (2010) Establishment of new wintering areas in herring co-occurs with peaks in the "first time/repeat spawner' ratio. Mar Ecol Prog Ser 409:189-198

Huseb $\varnothing$ A, Slotte A, Clausen LAW, Mosegaard H (2005) Mixing of populations or year class twinning in Norwegian spring spawning herring? Mar Freshw Res 56:763-772

Iles TD, Sinclair M (1982) Atlantic herring: stock discreteness and abundance. Science 215:627-633

Ito S-I, Rose KA, Megrey BA, Schweigert J, Hay D, Werner FE, Aita MN (2015) Geographic variation in Pacific herring growth in response to regime shifts in the North Pacific Ocean. Prog Oceanogr 138:331-347

Jakobsson J (1980) Exploitation of the Icelandic spring- and summer-spawning herring in relation to fisheries management, 1947-1977. Rapp P-V Reún Cons Int Explor Mer 177:23-42

Johannessen A, Nøttestad L, Fernö A, Langård L, Skaret G (2009) Two components of Northeast Atlantic herring within the same school during spawning: support for the existence of a metapopulation? ICES J Mar Sci 66:1740-1748

Johannessen A, Skaret G, Langård L, Slotte A, Husebø A, Fernö A (2014) The dynamics of a metapopulation: changes in life-history traits in resident herring that co-occur with oceanic herring during spawning. PLoS ONE 9:e102462

Jørstad KE, King DPF, Naevdal G (1991) Population structure of Atlantic herring, Clupea harengus L. J Fish Biol 39(36):43-52

Jørstad KE, Dahle G, Paulsen OI (1994) Genetic comparison between Pacific herring (Clupea pallasi) and a Norwegian fjord stock of Atlantic herring (Clupea harengus). Can J Fish Aquat Sci 51:233-239 
Karpov K, Kwiecien GS (1988) Conversions between total, fork and standard lengths for 41 species in 15 families of fish from California using preserved and fresh specimens. Administrative report no. 88-9. The Resources AgencyDepartment of Fish and Game, California

Kjesbu OS, Solemdal P, Bratland P, Fonn M (1996) Variation in annual egg production in individual captive Atlantic cod (Gadus morhua). Can J Fish Aquat Sci 53:610-620

Kurita Y, Kjesbu OS (2009) Fecundity estimation by oocyte packing density formulae in determinate and indeterminate spawners: theoretical considerations and applications. J Sea Res 61:188-196

Kurita Y, Meier S, Kjesbu OS (2003) Oocyte growth and fecundity regulation by atresia of Atlantic herring (Clupea harengus) in relation to body condition throughout the maturation cycle. J Sea Res 49:203-219

Laakkonen HM, Lajus DL, Strelkov P, Väinölä R (2013) Phylogeography of amphi-boreal fish: tracing the history of the Pacific herring Clupea pallasii in North-East European seas. Evol Biol 13:1-16

Laakkonen HM, Strelkov P, Lajus DL, Väinölä R (2015) Introgressive hybridization between the Atlantic and Pacific herrings (Clupea harengus and C. pallasii) in the north of Europe. Mar Biol 162:39-54

Lajus DL (1996) White Sea herring (Clupea pallasi marisalbi, Berg) population structure: interpopulation variation in frequency of chromosomal rearrangement. Cybium 20:279-294

Lamichhaney S, Fuentes-Pardo AP, Rafati N, Ryman N, McCracken GR, Bourne C, Singh R, Ruzzante DE, Andersson L (2017) Parallel adaptive evolution of geographically distant herring populations on both sides of the North Atlantic Ocean. Proc Natl Acad Sci USA 114:3452-3461

Landis WG, Duncan PB, Hayes EH, Markiewicz AJ, Thomas JF (2004) A regional retrospective assessment of the potential stressors causing the decline of the Cherry Point Pacific herring run. Hum Ecol Risk Assess 10:271-297

Lehodey P (2001) The pelagic ecosystem of the tropical Pacific Ocean: dynamic spatial modelling and biological consequences of ENSO. Prog Oceanogr 49:439-468

Libungan LA, Slotte A, Otis EO, Pálsson S (2016) Otolith variation in Pacific herring (Clupea pallasii) reflects mitogenomic variation rather than the subspecies classification. Polar Biol 39:1571-1579

Lie U, Dahl O, Østvedt OJ (1978) Aspects of the life history of the local herring stock in Lindåspollene, western Norway. Fisk Dir Skr Ser HavUnders 16:369-404

Ma Y, Kjesbu OS, Jørgensen T (1998) Effects of ration on the maturation and fecundity in captive Atlantic herring (Clupea harengus). Can J Fish Aquat Sci 55:900-908

Mantua NJ, Hare SR (2002) The pacific decadal oscillation. J Oceanogr 58:35-44

Martinez Barrio A, Lamichhaney S, Fan G et al (2016) The genetic basis for ecological adaptation of the Atlantic herring revealed by genome sequencing. Elife 5:e12081

McQuinn IH (1997) Metapopulations and the Atlantic herring. Rev Fish Biol Fisher 7:297-329

Messieh SN (1976) Fecundity studies on Atlantic herring from the southern Gulf of St. Lawrence and along the Nova Scotia coast. Trans Am Fish Soc 105:384-394
Mikkelsen N, Pedersen T, dos Santos Schmidt TC, Falk-Petersen I-B, Slotte A (2018) Are life histories of Norwegian fjord herring populations of Pacific ancestry similar to those of Atlantic or Pacific herring? J Mar Syst 180:237-245

Murua H, Kraus G, Saborido-Rey F, Witthames PR, Thorsen A, Junquera S (2003) Procedures to estimate fecundity of marine fish species in relation to their reproductive strategies. J Northw Atl Fish Sci 33:33-54

Nash RDM, Dickey-Collas M (2005) The influence of life history dynamics and environment on the determination of year class strength in North Sea herring (Clupea harengus L.). Fish Oceanogr 14:279-291

Near TJ, Eytan RI, Dornburg A, Kuhn KL, Moore JA, Davis MP, Wainwright PC, Friedman M, Smith WL (2012) Resolution of ray-finned fish phylogeny and timing of diversification. Proc Natl Acad Sci USA 109:13698-13703

Nøttestad L, Giske J, Holst JC, Huse G (1999) A length-based hypothesis for feeding migrations in pelagic fish. Can J Fish Aquat Sci 56:26-34

Ogle DH (2016) FSA: fisheries stock analysis. R package version 0.8 .10

Oksanen J, Blanchet FG, Kindt R, Legendre P, Minchin PR, O'Hara RB, Simpson GL, Solymos P, Stevens MHH, Wagner H (2016) Vegan: community ecology package. R package version 2.3-3

Óskarsson GJ (2008) Variation in body condition, fat content and growth rate of Icelandic summer-spawning herring Clupea harengus L. J Fish Biol 72:2655-2676

Óskarsson GJ, Taggart C (2006) Fecundity variation in Icelandic summer-spawning herring and implications for reproductive potential. ICES J Mar Sci 63:493-503

Óskarsson GJ, Kjesbu OS, Slotte A (2002) Predictions of realised fecundity and spawning time in Norwegian springspawning herring (Clupea harengus). J Sea Res 48:59-79

Óskarsson GJ, Taggart CT, Stephenson RL (2016) Fecundity and reproductive potential of Scotia-Fundy summer- and autumn-spawning herring (Clupea harengus L.). Can Tech Rep Fish Aquat Sci 3182:7

Óskarsson GJ, Taggart CT, Stephenson RL (2019) Variation in egg mass within two Atlantic herring Clupea harengus stocks. J Fish Biol 95:367-378

Pampoulie C, Slotte A, Óskarsson GJ et al (2015) Stock structure of Atlantic herring Clupea harengus in the Norwegian Sea and adjacent waters. Mar Ecol Prog Ser 522:219-230

Parrish BB, Saville A (1965) The biology of the North-east Atlantic herring populations. Oceanogr Mar Biol Ann Rev 3:323-373

Pesciaroli C, Cupini F, Selbmann L, Barghini P, Fenice M (2012) Temperature preferences of bacteria isolated from seawater collected in Kandalaksha Bay, White Sea, Russia. Polar Biol 35:435-445

R Core Team (2017) R: a language and environmental for statistical computing. R Foundation for Statistical Computing, Vienna, Austria

Rabin DJ, Barnhart RA (1977) Fecundity of Pacific herring, Clupea harengus pallasii, in Humboldt Bay. California Fish and Game: Conservation of wildlife through education 63:193-196 
Rass T, Wheeler A (1991) The nomenclature of the Pacific herring, Clupea pallasii Valenciennes, 1847. J Fish Biol 39:137-138

Sande HA, Persson A, Mehl S, Devine JA, dos Santos Schmidt TC, Karlsen O, Godiksen JA, Kjesbu OS (2019) Temperature and age effects on latitudinal growth dynamics of the commercially valuable gadoid Northeast Arctic saithe (Pollachius virens). Fish Res 213:94-104

Serrat A, Saborido-Rey F, Garcia-Fernandez C, Muñoz M, Lloret J, Thorsen A, Kjesbu OS (2019) New insights in oocyte dynamics shed light on the complexities associated with fish reproductive strategies. Sci Rep 9:18411

Silva FFG, Slotte A, Johannessen A, Kennedy J, Kjesbu OS (2013) Strategies for partition between body growth and reproductive investment in migratory and stationary populations of spring-spawning Atlantic herring (Clupea harengus L.). Fish Res 138:71-79

Sinclair M, Tremblay MJ (1984) Timing of spawning of Atlantic herring (Clupea harengus harengus) Populations and the match-mismatch theory. Can J Fish Aquat Sci 41:1055-1065

Slotte A (1999) Effects of fish length and condition on spawning migration in Norwegian spring spawning herring (Clupea harengus L.). Sarsia 84:111-127

Stearns SC (1992) The evolution of life histories. Oxford University Press, Oxford

IPCC (2018) Summary for policymakers. In: Masson-Delmotte V, Zhai P, Pörtner H-O et al (eds) Global warming of $1.5^{\circ} \mathrm{C}$. An IPCC Special Report on the impacts of global warming of $1.5^{\circ} \mathrm{C}$ above pre-industrial levels and related global greenhouse gas emission pathways, in the context of strengthening the global response to the threat of climate change, sustainable development, and efforts to eradicate poverty. World Meteorological Organization, Geneva, Switzerland

Sundby S (2000) Recruitment of Atlantic cod stocks in relation to temperature and advection of copepod populations. Sarsia 85:277-298

Sundby S, Drinkwater K (2007) On the mechanisms behind salinity anomaly signals of the northern North Atlantic. Prog Oceanogr 73:190-202
Sundby S, Drinkwater KF, Kjesbu OS (2016) The North Atlantic spring-bloom system-where the changing climate meets the winter dark. Front Mar Sci 3:Article 28

Tanasichuk RW, Ware DM (1987) Influence of interannual variations in winter sea temperature on fecundity and egg size in Pacific herring (Clupea harengus pallasi). Can J Fish Aquat Sci 44:1485-1495

Tanasichuk RW, Kristofferson AH, Gillman DV (1993) Comparison of some life history characteristics of Pacific herring (Clupea pallasi) from the Canadian Pacific Ocean and Beaufort Sea. Can J Fish Aquat Sci 50:964-971

Thorsen A, Kjesbu OS (2001) A rapid method for estimation of oocyte size and potential fecundity in Atlantic cod using a computer-aided particle analysis system. J Sea Res 46:295-308

Tojo N, Gordon HK, Funk FC (2007) Migration dynamics of Pacific herring (Clupea pallasii) and response to spring environmental variability in the southeastern Bering Sea. Deep Sea Res Part II 54:2832-2848

van Damme CJG, Dickey-Collas M, Rijnsdorp AD, Kjesbu OS (2009) Fecundity, atresia, and spawning strategies of Atlantic herring (Clupea harengus). Can J Fish Aquat Sci 66:2130-2141

Varpe O, Fiksen O, Slotte A (2005) Meta-ecosystems and biological energy transport from ocean to coast: the ecological importance of herring migration. Oecologia 146:443-451

Ware DM, Schweigert J (2001) Metapopulation structure and dynamics of British Columbia herring. Research Document 2001/127. Canadian Science Advisory Secretariat, Canada

Wuenschel MJ, Deroba JJ (2019) The reproductive biology of female Atlantic herring in U.S: waters: validating classification schemes for assessing the importance of spring and skipped spawning. Mar Coast Fish 11:487-505

Zuur AF, Ieno EN, Smith GM (2007) Analysing ecological data. Springer, New York

Publisher's Note Springer Nature remains neutral with regard to jurisdictional claims in published maps and institutional affiliations. 